\title{
A correlation linking the predicted mean vote and the mean thermal vote based on an investigation on the human thermal comfort in short-haul domestic flights
}

\author{
Carlo Giaconia, Aldo Orioli", Alessandra Di Gangi \\ D.E.I.M. Dipartimento di Energia, Ingegneria dell'Informazione e Modelli Matematici, Università degli Studi di Palermo, Viale delle Scienze Edificio 9, 90128 \\ Palermo, Italy
}

\section{A R T I C L E I N F O}

\section{Article history:}

Received 23 May 2014

Accepted 9 December 2014

Available online

\section{Keywords:}

Thermal comfort

Aircraft cabins

Air conditioning

\begin{abstract}
A B S T R A C T
The results of an experimental investigation on the human thermal comfort inside the cabin of some Airbus A319 aircrafts during 14 short-haul domestic flights, linking various Italian cities, are presented and used to define a correlation among the predicted mean vote (PMV), a procedure which is commonly used to assess the thermal comfort in inhabited environments, and the equivalent temperature and mean thermal vote (MTV), which are the parameters suggested by the European Standard EN ISO 145052 for the evaluation of the thermal environment in vehicles.

The measurements of the radiant temperature, air temperature and relative humidity during flights were performed. The air temperature varied between $22.2^{\circ} \mathrm{C}$ and $26.0^{\circ} \mathrm{C}$; the relative humidity ranged from $8.7 \%$ to $59.2 \%$. The calculated values of the PMV varied from -0.16 to 0.90 and were confirmed by the answers of the passengers. The equivalent temperature was evaluated using the equations of Fanger or on the basis of the values of the skin temperature measured on some volunteers.

The correlation linking the thermal sensation scales and zones used by the PMV and the MTV resulted quite accurate because the minimum value of the absolute difference between such environmental indexes equalled 0.0073 and the maximum difference did not exceed the value of 0.0589 . Even though the equivalent temperature and the MTV were specifically proposed to evaluate the thermal sensation in vehicles, their use may be effectively extended to the assessment of the thermal comfort in airplanes or other occupied places.
\end{abstract}

(C) 2014 Elsevier Ltd and The Ergonomics Society. All rights reserved.

\section{Introduction}

A comfortable environment in aircraft cabins is a priority concern in mass transportation. The parameters most frequently complained by passenger are the humidity, temperature, odor, and noise (Lee et al., 2000). Also the seat comfort, flight smoothness, and air quality are important for passenger comfort (Rankin et al., 2000); passengers who remain seated throughout the flight may risk edema or deep vein thrombosis (Brundrett, 2001).

The airline cabin attendants are exposed to several potential occupational hazards, including cosmic rays (Blettner et al., 2002). The crew operates within an environment that involves circadian dysrhythmia, reduced atmospheric pressure, mild hypoxia, low

\footnotetext{
* Corresponding author. Tel.: +39 (0)9123861914x905; fax: +39 (0)91484425.

E-mail address: orioli@dream.unipa.it (A. Orioli).
}

humidity, and exposure to sound, vibration and magnetic-field (Butler et al., 2000). Symptoms more often reported by the crew include: irritation of the eyes, nose and throat, headaches, lightheadedness and dizziness, fatigue, weakness and a decrease in performance, a general increase in feeling unwell, concentration difficulties and confusion, diarrhea, nausea, vomiting and gastrointestinal problems, numbness (head, limbs, lips, fingers), shortterm memory impairment and joint pain/muscle weakness (Michaelis, 2003). Some reports highlighting increased incidence of cancer among airline pilots and cabin crew have renewed concerns about possible exposure to harmful levels of cosmic radiation. Such a low energy ionizing radiation has been shown to cause DNA damages and induce genomic instability in human chromosomes (Lim, 2002). There have been some suggestions that crews have a higher-than-normal probability of developing cancer, since they are exposed to potential genotoxic factors. These also include airborne pollutants such as the engine combustion products, ozone, and 
electromagnetic fields (Cavallo et al., 2002). Actually, it was observed that airline pilots had an increased incidence of malignant melanoma of the skin and military pilots of other skin cancer (Hammar et al., 2002).

When aircraft operators have sought to reduce fuel cost by flying at higher altitudes, the energy cost of supplying an adequate amount of outside air for ventilation has increased; the increased pressurization of the outside air required for ventilation can add up to $2 \%$ to the fuel cost (Hocking 2000. The small air volume available per person in a fully occupied aircraft cabin accentuates the human bioeffluent factor in the maintenance of air quality (Hocking, 2002). The poor level of air quality may also cause intolerance to contact lenses and may be a health hazard to both passengers and crew members (Backman and Haghighat, 2000). The increased level of ozone can lead to respiratory problems for the upper airways and increased carbon dioxide may cause hyperventilation (Bergau, 1999).

The aircraft's environmental control systems (ECS) have to provide air supply, thermal control and cabin pressurization for the crew and passengers because the environmental conditions at the cruising altitudes, which since the 1970 s are about $12,000 \mathrm{~m}$, would not allow human organism to survive. To achieve the appropriate cabin ventilation and air conditioning, the outside air is bled from an intermediate stage of the engine compressor, adequately cooled and expanded before to be mixed with the recirculated air. Unfortunately, the need of reducing the fuel cost in airlines business competition has driven to adopt air handling systems that may lead to inadequate levels of thermal comfort inside the cabins of commercial airliners. Moreover, in order to reduce the risk of corrosion of metallic components and prevent the growth of microorganisms, the relative humidity in the cabin is usually set to very low levels that may affect the thermal comfort and increase the stress that is often felt by the crew and passengers. Most notable are "dryness" symptoms attributable to the low humidity and "fatigue" symptoms associated with factors such as disruption of circadian rhythm (Nagda and Koontz, 2003). Sometimes, perceived stress due to excess of work was associated with fatigue, feeling heavy-headed, headache and facial dermal symptoms (Lindgren et al., 2002). The cabin pressure can also impact on many aspects of the well-being of aircraft passengers. Some recent studies have shown that while the overall probability of achieving moderate hypoxia is low for healthy people, the risk is higher in passengers 60 years old and over, with cardiovascular or pulmonary diseases (Muhm et al., 2007; McNeely et al., 2011; Grun et al., 2012).

Several studies, which adopted experimental approaches based both on simulated and real flights, have taken into account the thermal comfort and air quality in aircraft cabins. The indoor air quality inside the cabins of Boeing 747-400, Airbus A330 and Airbus 340 aircrafts was investigated by Lee et al. (1999) for 16 flights during which the level of $\mathrm{CO}_{2}$ and the air temperature and relative humidity were measured every five minutes. Sometimes, the air was felt quite dry because the relative humidity varied between $4.9 \%$, which is a very small value, and $76.8 \%$ with a temporal variation dominated by a gradual decrease during the beginning and an increase at the end of the trip. The temperature in the aircraft cabin ranged from $19.3{ }^{\circ} \mathrm{C}$ to $27.1{ }^{\circ} \mathrm{C}$. The crew, which filled 185 questionnaires, rated the overall air quality in the surveyed flights to be acceptable (36\%) and adequate (32\%), while the air quality was considered poor by $21 \%$ of the crew. Haghighat et al. (1999) measured the temperature, relative humidity and carbon dioxide concentration aboard 43 flights on commercial airlines with duration of more than one hour. The data, which were collected on Douglas DC9, Boeing 767 and Airbus A320 and A340 aircrafts, were compared with the ASHRAE standards for thermal comfort and indoor air. The average values of temperature and humidity ranged within $20.2 \div 23.8{ }^{\circ} \mathrm{C}$ and $1.8 \% \div 18.5 \%$, respectively. The data showed that the air temperature was often below the recommended range $\left(20.2 \div 24.7{ }^{\circ} \mathrm{C}\right.$ in winter, $24.0 \div 27.4{ }^{\circ} \mathrm{C}$ in summer, with U.R. $\left.=50 \%\right)$ and the humidity was always too low. To evaluate the thermal comfort of the passengers on an Airbus A320, the PMV and the PPD were calculated during 21 flights. Assuming a light activity level and two air velocities of 0.1 and $0.15 \mathrm{~m} / \mathrm{s}$, the values of the PMV varied from -2.71 to -1.19 and from -1.26 to -0.21 in correspondence of the summer and winter conditions, respectively. The levels of relative humidity were very small on all flights and did not meet the lower limit of thermal comfort in ASHRAE standard 55-92.

The EC CabinAir Project monitored 14 flights that ranged from approximately 1 to $3 \mathrm{~h}$ (Ross et al., 2003). The parameters related to the air quality, cabin pressure, air and globe temperature, relative humidity and air speed were measured not only during passenger boarding and disembarkation, but also during all phases of flight from take-off, through cruise and then to descent. Moreover, the concentrations of carbon monoxide, carbon dioxide, nitrogen dioxide, volatile and semi-volatile organic compounds, bacteria and fungi, surface dust, dust mite and cat allergens, and ultrafine particles were collected. The ASHRAE Research Project RP-1262 aimed to investigate the link between perceived health symptoms and discomfort on one hand, and aircraft cabin environmental conditions and human factors on the other (Spicer et al., 2004). The measured data on aircrafts generally agree that cabins are non homogeneous thermal environments where about $25 \%$ of the occupants feel dissatisfied. Strøm-Tejsen et al. (2005a,b) performed measurements in a simulated section of an aircraft cabin with 21 seats installed in a climatic chamber capable of providing fresh outside air at very low humidity. Experiments simulating 7-hour transatlantic flights were carried out at four supply rates of outside air (1.4, 3.3, 4.7 and $9.4 \mathrm{~L} / \mathrm{s}$ per person), yielding average relative humidity levels of $28 \%, 16 \%$ and $11 \%$, respectively. A total of 68 subjects filled in questionnaires, but no significant differences of symptoms were found among the above four conditions. In order to investigate thermal effects, the temperature inside the cabin was set at three different levels $\left(20.6{ }^{\circ} \mathrm{C}, 23.3^{\circ} \mathrm{C}\right.$ and $\left.26.1^{\circ} \mathrm{C}\right)$, while maintaining the outside air supply rate and total air supply to the cabin at constant values.

Wang et al. (2008) used a full-scale section of a Boeing 767 cabin containing 35 manikins, which were equipped with body heaters and outlets of carbon dioxide to simulate breathing. The results of monitoring the environment quality in the cabin of a representative number of flights and aircraft were described by Chen in the report to the FAA issued by the Airliner Cabin Environmental Research (ACER) Program. Ozone levels were measured during 68 domestic flights (Chen et al., 2010). Measurements of pesticides were made on 15 domestic flights and 46 international flights. On most of the flights, the cabin temperature ranged from $22{ }^{\circ} \mathrm{C}$ to $29{ }^{\circ} \mathrm{C}$ and the humidity data demonstrated a trend of starting at around $35-50 \%$ at the beginning of the flight and dropping to around $10-25 \%$ as the flight progressed. Moreover, about 3700 flight attendants, selected in order to get a representative distribution of flight attendant characteristics, were queried about their symptoms, diagnoses, care seeking, treatment and work-related injuries.

The interrelation between local and overall thermal comfort of passengers in a $30 \mathrm{~m}$ long pressure vessel holding the first $16 \mathrm{~m}$ of a complete wide body A310-200 aircraft was investigated by Park et al. (2011). During 11 simulated 3.5h flights and two 7h flights, 40 test persons filled out questionnaires concerning their perceived overall and local thermal comfort at temperatures ranging from $20{ }^{\circ} \mathrm{C}$ to $25^{\circ} \mathrm{C}$. In order to verify if the high ratio of thermal dissatisfaction in the aircraft cabin reported in literature were caused by local discomfort, the physical and subjective data related to 11 body segments were used to evaluate the PMV, the thermal 
Table 1

Data of flights.

\begin{tabular}{|c|c|c|c|c|c|c|c|c|}
\hline Flight no. & Air route & Passengers & Distance $[\mathrm{km}]$ & Altitude [m] & Date & Take-off & Landing & Duration \\
\hline 1 & Palermo-Verona & 140 & 818 & 11278 & 08 Sep. 2011 & $08: 34$ & 09:57 & $1: 23$ \\
\hline 2 & Verona-Palermo & 70 & 818 & 11278 & 08 Sep. 2011 & $10: 45$ & $11: 52$ & $1: 07$ \\
\hline 3 & Palermo-Verona & 143 & 818 & 11278 & 12 Sep. 2011 & $07: 23$ & $08: 40$ & $1: 17$ \\
\hline 4 & Verona-Palermo & 113 & 818 & 11278 & 12 Sep. 2011 & $09: 27$ & $10: 37$ & 1:09 \\
\hline 5 & Palermo-Milan & 146 & 887 & 11278 & 12 Sep. 2011 & $12: 15$ & $13: 32$ & $1: 17$ \\
\hline 6 & Milan-Palermo & 134 & 887 & 11278 & 12 Sep. 2011 & $14: 37$ & $15: 57$ & $1: 20$ \\
\hline 7 & Palermo-Rome & 87 & 426 & 9754 & 08 Oct. 2011 & $14: 59$ & $15: 47$ & $0: 48$ \\
\hline 8 & Rome-Palermo & 95 & 426 & 9754 & 08 Oct. 2011 & $17: 11$ & $17: 50$ & $0: 39$ \\
\hline 9 & Palermo-Turin & 81 & 905 & 10680 & 08 Oct. 2011 & $18: 49$ & $20: 15$ & $1: 26$ \\
\hline 10 & Turin-Palermo & 84 & 905 & 10680 & 08 Oct. 2011 & $21: 05$ & $22: 12$ & $1: 07$ \\
\hline 11 & Palermo-Rome & 107 & 426 & 9754 & 10 Oct. 2011 & $15: 12$ & $16: 01$ & $0: 49$ \\
\hline 12 & Rome-Palermo & 74 & 426 & 9754 & 10 Oct. 2011 & $17: 16$ & $17: 53$ & $0: 37$ \\
\hline 13 & Palermo-Rome & 102 & 426 & 9754 & 10 Oct. 2011 & $19: 55$ & $20: 45$ & $0: 50$ \\
\hline 14 & Rome-Palermo & 80 & 426 & 9754 & 10 Oct. 2011 & $22: 26$ & $23: 03$ & $0: 37$ \\
\hline
\end{tabular}

sensation mean vote and the PPD. While the PMV predicted the overall thermal sensation relatively well, the thermal dissatisfaction of the test persons were higher than the PPD calculated on the basis of the local thermal discomfort. The local thermal perception of some body segments resulted to be significantly different from the overall thermal perception and also different between satisfied and dissatisfied groups under the same overall thermal sensation or at the same air temperature. Anyway, it was observed that the results of the study may have been different inside real aircraft cabins because the experiments were performed without fuselage cooling and with air velocity lower than in a typical aircraft cabin environment. The ACER Center conducted an environmental monitoring in the passenger cabin of 83 commercial flights on six aircraft models (2 Airbus and 4 Boeing), flying U.S. domestic and international routes (Spengler et al., 2012). Except for low pressure, occasionally high ozone, extremely dry air and perhaps slightly higher noise levels, the air quality and environmental conditions in the passenger cabin of commercial airplanes were found to be comparable or better than conditions reported for offices, schools and residences, with a few exceptions.

Many authors have also investigated the effects of the low levels of relative humidity by questioning the crew and passengers. Nagda and Hodgson (2001) pointed out that some subjects were not always able to perceive low humidity or changes in the humidity level and that the perception of humidity did not vary with the duration of exposure. Moreover, it was observed that the complaints of dryness decreased by lowering the air temperature with a constant relative humidity; adversely, the perceived staleness of air increases and the perceived acceptability of air decreases with a rise in either the air temperature or humidity. Lindgren et al. (2005, 2007) investigated the perception of cabin air quality among Swedish commercial airline crew and the effect of humidifying the air cabin in eight intercontinental flights with a Boeing 767 aircraft. Grün et al. (2012) analysed the impact of low humidity on the human well-being during simulated $7 \mathrm{~h}$ long-haul flights. Questionnaires were filled in by 40 subjects who experienced relative humidity varying between $10 \%$ and $40 \%$ at a temperature range of
$21{ }^{\circ} \mathrm{C}-25^{\circ} \mathrm{C}$ and atmospheric pressure between $753 \mathrm{hPa}$ and ambient conditions. Using the data measured during 14 short-haul domestic flights, a relationship between the air relative humidity and $\mathrm{CO}_{2}$ concentration was proposed and tested by Giaconia et al. (2013). The relationship was used to predict the possibility of increasing the comfort of the crew and passengers reaching a suitable compromise between low levels of $\mathrm{CO}_{2}$ and sufficient values of relative humidity in the aircraft cabin.

In this paper the experimental study is presented of the thermal comfort that was carried out on 14 short-haul domestic flights linking various Italian cities. On the basis of the measurements of the parameters affecting the thermal comfort, performed inside the cabin of an Airbus A319, the values of the PMV and the PPD were calculated and compared with the answers of the passengers who filled in questionnaires. Moreover, observing that the environmental conditions in the cabins of commercial airliners may seem similar to the ones that are usually present in crowded means of public transport, such as trains and long-haul buses, it was tried to verify if the level of thermal comfort could be assessed by means of the equivalent temperature and the MTV, which are the parameters suggested by the European Standard EN ISO 14505-2 (2007) for the evaluation of the thermal environment in vehicles. The equivalent temperature was evaluated using both the equations of Fanger and the values of the skin temperature measured on some volunteers during flights. The comparison between the values of the PMV and the MTV permitted to define a direct correlation linking these comfort indexes, which resulted quite accurate in the range of the analysed data.

\section{Experimental assessment of thermal comfort with the predicted mean vote}

The experimental assessment described in this paper was conducted in the passenger cabin of some Airbus A319 during the 14 short-haul domestic flights listed in Table 1.

The human thermal comfort is governed by many environmental and personal variables. These have to be acquired to achieve

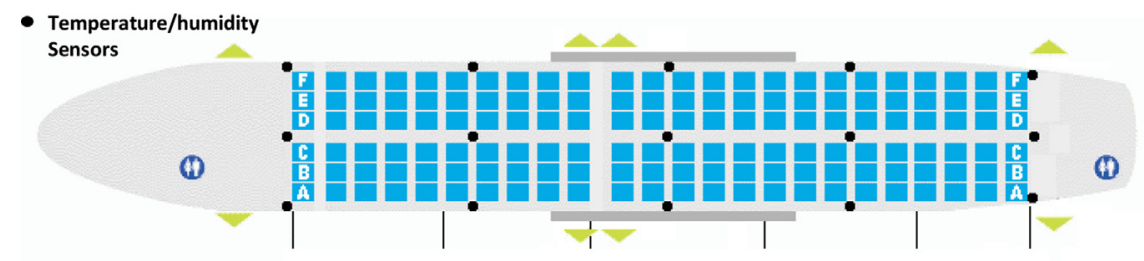

Airbuss A 319

Fig. 1. Position of the temperature/humidity sensors in the cabin. 


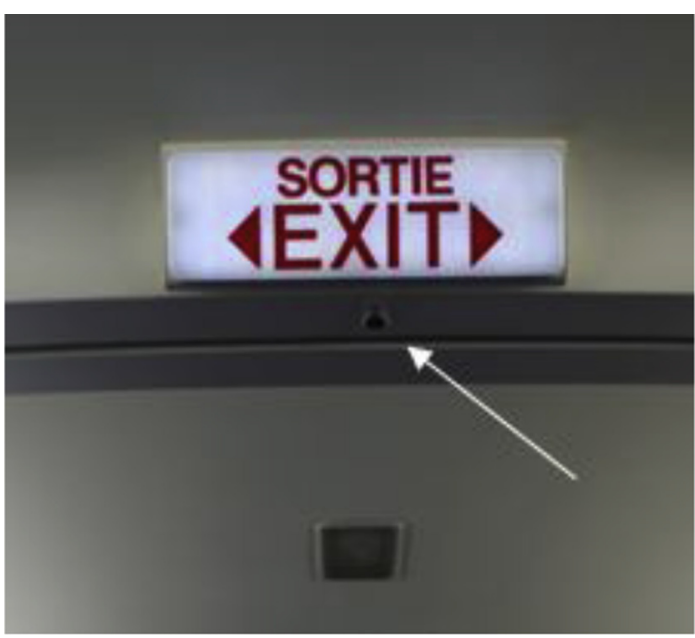

Fig. 2. Position of a temperature/humidity sensor in the ceiling of the cabin.

reliable results from the calculations of the PMV and PPD (Fanger, 1967, 1970, 1982). The air temperature and relative humidity measurements during flights were performed by means of DS1923 iButton ${ }^{\circledR}$ micro-loggers produced by Dallas Semiconductors. The DS1923 is a rugged, self-sufficient system that measures temperature and/or humidity at a user-defined rate and records the result in a protected memory section. The resolutions declared by the manufacturer are $0.5{ }^{\circ} \mathrm{C}$ with 8 bit resolution or $0.0625^{\circ} \mathrm{C}$ with 11 bit resolution and $4 \% \mathrm{RH}$ or $0.04 \% \mathrm{Rh}$ for temperature and relative humidity, respectively. The temperature accuracy is better than $\pm 0.5{ }^{\circ} \mathrm{C}$; each element can be laboratory calibrated and the calibration result stored in a memory register.

The data were sampled every minute from boarding to disembarking. With the aim of verifying the uniformity of the environmental conditions in the cabin, the air temperature and relative humidity were measured in 15 points that were distributed regularly along the airplane in order to divide the cabin in five sections with about the same volume; Fig. 1 shows the position of the sensors.

The temperature/humidity sensors were placed in the middle of the ceiling and in the upper part of the walls of the cabin, as it is shown in Fig. 2 and Fig. 3.

It is obvious that it would have been better not to place the sensors on the inside surfaces of the cabin and get measurements of

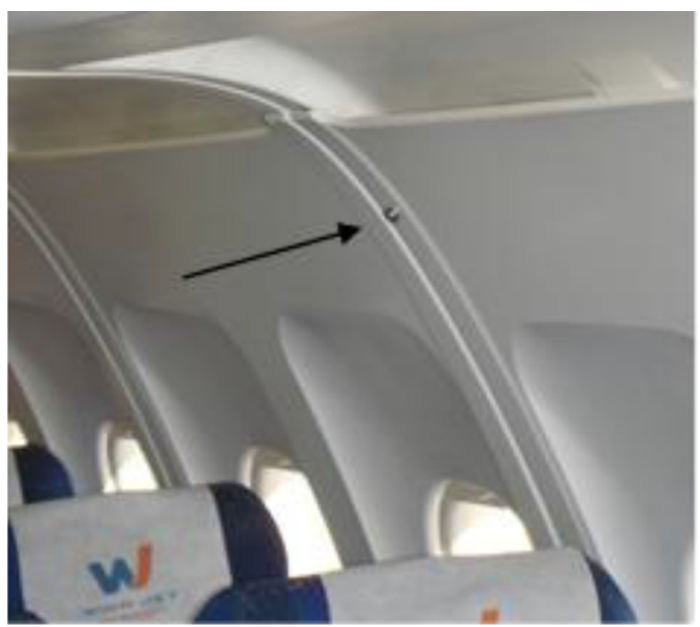

Fig. 3. Position of a temperature/humidity sensor in the wall of the cabin.
Table 2

Dispersion of the measurements with reference to the data measured in the middle zone of the cabin.

\begin{tabular}{|c|c|c|c|c|c|c|}
\hline \multirow{2}{*}{$\begin{array}{l}\text { Flight } \\
\text { no. }\end{array}$} & \multicolumn{3}{|c|}{ Temperature $\left[{ }^{\circ} \mathrm{C}\right]$} & \multicolumn{3}{|c|}{ Relative humidity [\%] } \\
\hline & $\begin{array}{l}\text { Mean } \\
\text { difference }\end{array}$ & $\begin{array}{l}\text { Abs. Mean } \\
\text { difference }\end{array}$ & $\begin{array}{l}\text { Standard } \\
\text { deviation }\end{array}$ & $\begin{array}{l}\text { Mean } \\
\text { difference }\end{array}$ & $\begin{array}{l}\text { Abs. Mean } \\
\text { difference }\end{array}$ & $\begin{array}{l}\text { Standard } \\
\text { deviation }\end{array}$ \\
\hline 1 & -0.18 & 0.48 & 0.59 & 0.60 & 1.99 & 2.43 \\
\hline 2 & 0.16 & 0.55 & 0.68 & 0.79 & 1.42 & 1.67 \\
\hline 3 & 0.16 & 0.48 & 0.67 & 1.96 & 2.29 & 1.89 \\
\hline 4 & 0.21 & 0.58 & 0.72 & 1.93 & 2.70 & 3.00 \\
\hline 5 & 0.65 & 0.93 & 1.03 & 1.25 & 2.00 & 2.31 \\
\hline 6 & 0.05 & 0.65 & 0.85 & 0.29 & 1.62 & 2.00 \\
\hline 7 & 0.11 & 0.52 & 0.74 & 1.03 & 1.67 & 2.13 \\
\hline 8 & 0.14 & 0.30 & 0.33 & 0.22 & 1.58 & 1.99 \\
\hline 9 & -0.44 & 0.63 & 0.68 & 0.68 & 1.53 & 2.03 \\
\hline 10 & -1.03 & 1.03 & 0.74 & -1.73 & 2.05 & 1.79 \\
\hline 11 & 0.06 & 0.65 & 0.79 & 0.39 & 1.72 & 2.38 \\
\hline 12 & -0.13 & 0.68 & 0.78 & -0.10 & 2.55 & 3.05 \\
\hline 13 & -0.52 & 0.65 & 0.53 & -1.01 & 2.09 & 2.24 \\
\hline 14 & -0.18 & 0.29 & 0.33 & 0.23 & 1.28 & 1.63 \\
\hline
\end{tabular}

the temperature and humidity in correspondence of the positions occupied by the passengers. Unfortunately, because the measurements were performed during actual commercial flights, the installation of the sensors near the bodies of the passengers was considered quite improper by the airline company. Even if some differences, of the same order of magnitude of the accuracy of the used sensors, were found in the sampled data, an acceptable uniformity of the air temperature and relative humidity distribution throughout the cabin was observed. Table 2 lists some values that describe the differences observed between the data measured in the middle zone of the cabin and the data collected in the other four zones.

The values of the air temperature and relative humidity in the middle zone of the cabin were used to represent the environmental conditions of the entire cabin. The mean radiant temperature in the middle zone of the cabin was measured every minute by means of a globe thermometer DIN IEC 751 connected to a BABUC/M portable data logger. The minimum, maximum and average measured values of the air temperature, relative humidity and mean radiant temperature are listed in Table 3.

The air temperature varied between $22.2{ }^{\circ} \mathrm{C}$ and $26.0^{\circ} \mathrm{C}$; the average of the air temperature ranged from $23.1^{\circ} \mathrm{C}$ to $25.0^{\circ} \mathrm{C}$. The relative humidity varied from $8.7 \%$, which is a very low value, to $59.2 \%$. The greatest values of the relative humidity were reached in correspondence of the take-offs. At cruising altitudes, where

Table 3

Minimum, maximum and average measured values of the air temperature, relative humidity and mean radiant temperature from take-off to touchdown.

\begin{tabular}{|c|c|c|c|c|c|c|c|c|c|}
\hline \multirow[t]{2}{*}{$\begin{array}{l}\text { Flight } \\
\text { no. }\end{array}$} & \multicolumn{3}{|c|}{ Air temperature $\left[{ }^{\circ} \mathrm{C}\right]$} & \multicolumn{3}{|c|}{$\begin{array}{l}\text { Relative } \\
\text { humidity [\%] }\end{array}$} & \multicolumn{3}{|c|}{$\begin{array}{l}\text { Mean radiant } \\
\text { temperature }\left[{ }^{\circ} \mathrm{C}\right]\end{array}$} \\
\hline & Min. & Max. & Average & Min. & Max. & Average & Min. & Max. & Average \\
\hline 1 & 24.7 & 25.5 & 25.0 & 10.5 & 55.0 & 20.2 & 25.8 & 26.6 & 26.1 \\
\hline 2 & 23.0 & 25.8 & 24.0 & 8.7 & 51.5 & 20.2 & 24.1 & 27.0 & 25.1 \\
\hline 3 & 23.1 & 25.7 & 24.1 & 11.2 & 59.2 & 22.1 & 24.3 & 26.9 & 25.2 \\
\hline 4 & 24.3 & 25.9 & 24.7 & 10.7 & 54.0 & 20.7 & 25.5 & 27.0 & 25.9 \\
\hline 5 & 23.1 & 26.0 & 23.9 & 11.6 & 54.5 & 21.1 & 24.3 & 27.2 & 25.1 \\
\hline 6 & 23.7 & 26.0 & 24.2 & 10.3 & 43.8 & 17.9 & 24.8 & 27.2 & 25.3 \\
\hline 7 & 23.9 & 24.9 & 24.5 & 13.0 & 44.0 & 22.3 & 24.7 & 26.5 & 25.6 \\
\hline 8 & 23.2 & 24.9 & 24.1 & 17.5 & 33.0 & 22.1 & 24.4 & 25.7 & 25.2 \\
\hline 9 & 22.2 & 24.0 & 23.1 & 14.9 & 38.4 & 19.3 & 24.6 & 26.4 & 25.7 \\
\hline 10 & 23.4 & 24.4 & 24.0 & 14.4 & 31.1 & 19.2 & 25.3 & 26.9 & 26.2 \\
\hline 11 & 23.7 & 25.0 & 24.5 & 16.1 & 39.0 & 23.2 & 23.3 & 24.7 & 24.0 \\
\hline 12 & 23.7 & 24.8 & 24.3 & 19.1 & 38.5 & 24.7 & 23.0 & 27.5 & 25.0 \\
\hline 13 & 23.7 & 25.2 & 24.4 & 18.6 & 42.3 & 27.0 & 24.3 & 25.7 & 25.1 \\
\hline 14 & 23.4 & 24.6 & 24.1 & 17.5 & 40.0 & 25.9 & 24.9 & 26.4 & 25.6 \\
\hline
\end{tabular}


airliners fly for the most part of the time, the minimum values of the relative humidity were generally observed. The average of the relative humidity ranged from $17.9 \%$ to $27.0 \%$. The mean radiant temperature varied between $23.0^{\circ} \mathrm{C}$ and $27.5^{\circ} \mathrm{C}$; the average of the mean radiant temperature ranged from $24.0^{\circ} \mathrm{C}$ to $26.2^{\circ} \mathrm{C}$.

The air velocity is another parameter that significantly affects the thermal comfort. In aircrafts the conditioned air is ejected from the ceiling outlets generating circular airflow patterns in the cabin. Moreover, each passenger can use adjustable nozzles to locally modify the air velocity and direction in order to achieve their personal thermal comfort. It was established that the air leaves the outlets at a velocity greater than $2.5 \mathrm{~m} / \mathrm{s}$ and keeps values varying between 0.1 and $0.35 \mathrm{~m} / \mathrm{s}$ close to the passenger's body. Because the air outlets and adjustable nozzles are not adequately far from passengers, the velocity field in the occupied zone of the cabin is not quite uniform and it is very difficult to define a reliable average value of the air velocity on the basis of the measurements performed in some points of the cabin. For this reason, instead of using unreliable data, the results of the air velocity measurements were only used to confirm that a value of $0.1 \mathrm{~m} / \mathrm{s}$ could be considered averagely adequate to calculate the PMV and the PPD. The following values of the rate of metabolic heat production $M$ and clothing thermal resistance $R_{C l}$ were also used to perform the calculations:

$$
\begin{aligned}
& \text { - } M=63.91 \mathrm{~W} / \mathrm{m}^{2} \text { (1.1 met) } \\
& \text { - } R_{c l}=0.132 \mathrm{~m}^{2} \mathrm{~K} / \mathrm{W} \text { (0.85 clo) }
\end{aligned}
$$

A metabolic rate of $63.91 \mathrm{~W} / \mathrm{m}^{2}$ corresponds to the value of 1.1 met obtained as the average of the values assumed for seated people (1.0 met) and the aircraft crew (1.2 met) (ANSI/ASHRAE, 2004). The value of 0.85 clo used for the clothing thermal resistance is evaluated adding the value of $0.6 \mathrm{clo}$, which represents the passenger clothing fit for the climatic conditions in Italy at the end of summer, to the additional thermal insulation of $0.25 \mathrm{clo}$, which accounts for the airplane seats. The rate of mechanical work accomplished by the occupant was considered negligible. To calculate clothing area factor $f_{c l}$ and convection heat transfer coefficient $h_{c}$, the following equations were used (ASHRAE, 2009):

$f_{c l}=\left\{\begin{array}{l}1.0+0.2 R_{c l} \text { if } R_{c l}<0.5 \text { clo } \\ 1.05+0.1 R_{c l} \text { if } R_{c l}>0.5 \text { clo }\end{array}\right.$

$h_{c}=\left\{\begin{array}{l}2.38\left(t_{c l}-t_{a}\right)^{0.25} \text { if } 2.38\left(t_{c l}-t_{a}\right)^{0.25}>12.1 \sqrt{V} \\ 12.1 \sqrt{V} \text { if } 2.38\left(t_{c l}-t_{a}\right)^{0.25}<12.1 \sqrt{V}\end{array}\right.$

where:

$t_{c l}=$ mean temperature of the outer surface of the clothed body $\left[{ }^{\circ} \mathrm{C}\right]$

$$
t_{a}=\text { air temperature }\left[{ }^{\circ} \mathrm{C}\right]
$$$$
V=\text { air velocity }[\mathrm{m} / \mathrm{s}]
$$

The PMV and the PPD were calculated using the data of the air temperature, relative humidity and mean radiant temperature measured during the flights listed in Table 1. The PMV varied between -0.16 and 0.90 from take-off to touchdown; the PPD ranged from $5.0 \%$ to $22.1 \%$. In order to confirm the obtained results, questionnaires were distributed to the passengers. Unfortunately, dealing with non-simulated flights, it was difficult to find a sufficient number of cooperative passengers. Only 67 passengers accepted to fill in the questionnaires. The age of passengers ranged from 22 to 50 , with a mean value of 31.8 ; about $46 \%$ of the passengers were women, $54 \%$ were men. Questionnaires were handed over about $30 \mathrm{~min}$ after take-off. The thermal sensation votes ranged from -1 (slightly cool) and +1 (slightly warm). Although the number the questionnaires was too small to be of statistical significance, a fairly good concordance was observed with the calculated values of the PMV because the average of the thermal sensation votes varied from 0.16 to 0.35 . Even if low values of the relative humidity were present during flight, the passengers did not perceive the effect of the air dryness on the thermal comfort level. Actually, the exposure to low relative humidity levels, rather than influence the perception of thermal comfort, can frequently induce unpleasant secondary symptoms, such as dry itchy o irritated eyes, dry or stuffy nose and skin dryness or irritation.

\section{Assessment of the equivalent temperature}

The equivalent temperature is an environmental index described by the European Standard EN ISO 14505-2, which provides guidelines for the assessment of the thermal conditions inside a vehicle compartment. Like other transportation means, such as trains and long-haul buses, aircrafts are spaces where the passengers suffer from lack of room and feel uncomfortable because of occupant density. Hocking (2000) reported that the passengers in a fully loaded aircraft typically have about $1 \div 2 \mathrm{~m}^{3}$ of available space per person, roughly $1 / 10$ th that of a typical office worker or a spectator in an auditorium. It was calculated that, with $1 \mathrm{~m}^{3}$ of space per person and without any air change, it would take only $2.3 \mathrm{~min}$ for the concentration of $\mathrm{CO}_{2}$ in that space to exceed the 1000 ppmv comfort ceiling recommended by the ASHRAE. Airplane cabins have become even more crowded over the last few decades because the seat pitch has decreased from about $86 \mathrm{~cm}$ to $79 \mathrm{~cm}$, or even less. Actually, the lack of legroom is of the biggest complaints among flyers, especially on flights over four hours in length (Tripadvisor, 2012).

The equivalent temperature is defined as the temperature of a homogeneous space, with a value of the mean radiant temperature equal to the air temperature and zero air velocity, in which a person experiences the same heat loss by convection and radiation as in the actual conditions under assessment. The equivalent temperature, which integrates the independent effects of the thermal exchange for convection and radiation from the human body, is an objective index that does not take into account the human perception and sensation or other subjective aspects. Many studies have analysed the thermal comfort in vehicles by assessing the equivalent temperature by means of multi-segmented manikins or heated sensors (Wyon, 1989; Wyon et al., 1989; Nilsson et al., 1997; Gameiro da Silva, 2002; Nilsson et al., 2003; Quintela et al., 2004; Nilsson, 2007). The total and local heat fluxes from the thermal manikins were determined for different climatic conditions and compared with the thermal sensation votes of subjects exposed to the same conditions. On the basis of the value of the equivalent temperature it was possible to predict the heat balance of the human body under conditions in, or close to, the thermo-neutral zone. The thermo-neutral zone describes the range of temperatures of the environment in which a person can keep a normal body temperature because the basal rate of heat production is in equilibrium with the rate of heat loss to the external environment. It was found that the values of the equivalent temperature of a defined environment are closely related to how the people perceive the thermal conditions when they are exposed to the same environment. The equivalent temperature can be calculated by means of the following equations:

$$
\begin{aligned}
& t_{e q}=t_{s}-\frac{Q_{s}}{h_{r c}}=t_{s}-\frac{R+C}{h_{r}+h_{c}} \\
& R=h_{r}\left(t_{s}-t_{m r}\right)
\end{aligned}
$$


$C=h_{c}\left(t_{s}-t_{a}\right)$

where:

$$
\begin{aligned}
& t_{e q}=\text { equivalent temperature }\left[{ }^{\circ} \mathrm{C}\right] \\
& t_{s}=\text { surface temperature }\left[{ }^{\circ} \mathrm{C}\right] \\
& Q_{s}=\text { total sensible heat loss per unit area }\left[\mathrm{W} / \mathrm{m}^{2}\right] \\
& h_{r c}=\text { combined heat transfer coefficient }\left[\mathrm{W} / \mathrm{m}^{2}{ }^{\circ} \mathrm{C}\right] \\
& R=\text { radiation heat loss per unit area }\left[\mathrm{W} / \mathrm{m}^{2}\right] \\
& C=\text { convective heat loss per unit area }\left[\mathrm{W} / \mathrm{m}^{2}\right] \\
& h_{r}=\text { radiation heat transfer coefficient }\left[\mathrm{W} / \mathrm{m}^{2}{ }^{\circ} \mathrm{C}\right] \\
& t_{m r}=\text { mean radiant temperature of the environment }\left[{ }^{\circ} \mathrm{C}\right]
\end{aligned}
$$

In the previous equations $t_{s}$ is the temperature of the surface exposed to the environment, which corresponds to the whole body skin, if the person is naked. Because the sensible heat emitted by the skin is transmitted to the surrounding environment through the clothing, the following equations have to be used:

$$
\begin{aligned}
& R=f_{c l} h_{r}\left(t_{c l}-t_{m r}\right) \\
& C=f_{c l} h_{c}\left(t_{c l}-t_{a}\right) \\
& Q_{s}=R+C=\frac{t_{s k}-t_{c l}}{R_{c l}}
\end{aligned}
$$

where $t_{s k}$ is the skin temperature of the body and $R_{c l}$ is the clothing resistance. If temperature $t_{c l}$ is eliminated in the above equations, total sensible heat loss $Q_{S}$ can be expressed with the following equation:

$Q_{s}=R+C=\frac{f_{c l}\left[\left(h_{r}+h_{c}\right) t_{s k}-h_{r} t_{m r}-h_{c} t_{a}\right]}{1+f_{c l} R_{c l}\left(h_{r}+h_{c}\right)}$

which is obviously valid if the person, or the manikin, is in steady-state conditions. As opposed to thermal manikins, the human body also dissipates latent heat by sweat evaporation, natural diffusion of water through the skin and vapour loss from the respiratory tract to the inhaled air during respiration. For this reason, when sweating thermal manikins are not used, the surface temperature of a thermal manikin should be set to a value higher than the human skin temperature in order to make the heat loss from the manikin equal to total heat $Q_{T}$ emitted by the person (Richards and Mattle, 2002; Wang, 2008; Wang et al., 2010). The rate of sensible and latent heat loss from the body may be evaluated by means of the following relations that Fanger $(1967,1970,1982)$ used to calculate the PMV:

$Q_{T}=Q_{s}+Q_{l}$

$Q_{s}=R+C+C_{r e s}$

$Q_{l}=E_{r s w}+E_{d i f}+E_{r e s}$

with:

$$
\begin{aligned}
& R=3.96 \cdot 10^{8} f_{c l}\left[\left(t_{c l}+273.15\right)^{4}-\left(t_{m r}+273.15\right)^{4}\right] \\
& C_{\text {res }}=0.0014 M\left(34-t_{a}\right) \\
& E_{r s w}=0.42(M-W-58.15) \\
& E_{\text {dif }}=3.05\left[5.73-0.007(M-W)-p_{v}\right]
\end{aligned}
$$

$E_{\text {res }}=0.0173 M\left(5.87-p_{v}\right)$

where:

$Q_{l}=$ rate of latent heat loss $\left[\mathrm{W} / \mathrm{m}^{2}\right]$

$C_{\text {res }}=$ rate of sensible heat loss due to respiration $\left[\mathrm{W} / \mathrm{m}^{2}\right]$

$E_{r s w}=$ rate of latent heat loss due to sweating $\left[\mathrm{W} / \mathrm{m}^{2}\right]$

$E_{d i f}=$ rate of latent heat loss due to water diffusion through the skin $\left[\mathrm{W} / \mathrm{m}^{2}\right]$

$E_{\text {res }}=$ rate of latent heat loss due to respiration $\left[\mathrm{W} / \mathrm{m}^{2}\right]$

$p_{v}=$ vapour pressure in the cabin $[\mathrm{kPa}]$

Eq. (7) can be used to calculate convective heat loss $C$ in Eq. (11). In order to evaluate the human body equivalent temperature $t_{e q}^{*}$, Eq. (3) has to be replaced with the following equation:

$t_{e q}^{*}=t_{s k}-\frac{Q_{T}}{h_{r c}}$

Skin temperature $t_{s k}$ may be calculated with the following equation (Rohles and Nevins, 1971),

$t_{s k}=37.5-0.0275 Q_{T}$

The skin temperature may be also experimentally measured and used in Eq. (9) to directly calculate the sensible heat loss without the need of Eq. (11). The value of the mean skin temperature of the human body is usually obtained by adding the products of a finite number of local skin temperatures and the corresponding weighting factors. As it is reported by Liu et al. (2011), many methods for calculating the mean skin temperature, based on different numbers of skin temperature sites and weighting factors, have been deduced from the field of physiology. Gagge et al. (1969) and Bulcao et al. (2000) used a 10-site weighed calculation method. Hasebe et al. (1995) and Huizenga et al. (2004) proposed a 7-site method. Olesen (1984) claimed that in warm conditions, when skin temperature is rather uniform, $2 \div 4$ measurement sites may be enough, while in cold conditions $8 \div 12$ skin measurement sites may be necessary.

With the aim of investigating the reliability of the experimental approach, the skin temperature of two volunteers, who seated in the middle zone of the cabin, was measured every minute from boarding to disembarking. Three iButton ${ }^{\circledR}$ devices were located on the left chest, right calf and left forearm of each volunteer in order to evaluate mean skin temperature $t_{m s k}$ by means of the following 3-site weighted equation (Burton, 1935):

$t_{m s k}=0.50 t_{1}+0.36 t_{2}+0.14 t_{3}$

where:

$$
\begin{aligned}
& t_{1}=\text { left chest skin temperature }\left[{ }^{\circ} \mathrm{C}\right] \\
& t_{2}=\text { right calf skin temperature }\left[{ }^{\circ} \mathrm{C}\right] \\
& t_{3}=\text { left forearm skin temperature }\left[{ }^{\circ} \mathrm{C}\right]
\end{aligned}
$$

Table 4

Thermal sensation zones.

\begin{tabular}{llll}
\hline Zone no. & $\begin{array}{l}\text { Thermal } \\
\text { sensation }\end{array}$ & Boundaries & \\
\cline { 3 - 4 } & Winter & Summer \\
\hline 1 & Too cold & $t_{e q}<18.0{ }^{\circ} \mathrm{C}$ & $t_{e q}<20.0{ }^{\circ} \mathrm{C}$ \\
2 & Cold but & $18.0^{\circ} \mathrm{C}<t_{e q}<21.0^{\circ} \mathrm{C}$ & $20.0^{\circ} \mathrm{C}<t_{e q}<23.8^{\circ} \mathrm{C}$ \\
& comfortable & & \\
3 & Neutral & $21.0{ }^{\circ} \mathrm{C}<t_{e q}<24.0{ }^{\circ} \mathrm{C}$ & $23.8{ }^{\circ} \mathrm{C}<t_{e q}<26.7{ }^{\circ} \mathrm{C}$ \\
4 & Warm but & $24.0{ }^{\circ} \mathrm{C}<t_{e q}<27.0{ }^{\circ} \mathrm{C}$ & $26.7{ }^{\circ} \mathrm{C}<t_{e q}<30.0^{\circ} \mathrm{C}$ \\
5 & comfortable & & \\
\hline
\end{tabular}


Table 5

Values of the equivalent temperature.

\begin{tabular}{|c|c|c|c|c|c|c|}
\hline \multirow[t]{3}{*}{ Flight no. } & \multicolumn{6}{|c|}{ Equivalent temperature $\left[{ }^{\circ} \mathrm{C}\right]$} \\
\hline & \multicolumn{3}{|c|}{$t_{s k}$ calculated with Eq. (19) } & \multicolumn{3}{|c|}{$t_{m s k}$ calculated with Eq. $(20)$} \\
\hline & Min. & Max. & Average & Min. & Max. & Average \\
\hline 1 & 25.95 & 27.20 & 26.27 & 25.48 & 26.87 & 25.93 \\
\hline 2 & 25.10 & 27.35 & 25.71 & 24.79 & 26.98 & 25.49 \\
\hline 3 & 25.21 & 27.52 & 25.80 & 24.96 & 27.11 & 25.50 \\
\hline 4 & 25.75 & 27.50 & 26.13 & 24.91 & 26.93 & 25.47 \\
\hline 5 & 25.20 & 27.66 & 25.69 & 24.71 & 27.11 & 25.25 \\
\hline 6 & 25.36 & 27.40 & 25.78 & 24.68 & 27.11 & 25.65 \\
\hline 7 & 25.72 & 26.55 & 26.02 & 25.78 & 26.59 & 26.18 \\
\hline 8 & 25.43 & 26.35 & 25.79 & 25.58 & 26.24 & 25.84 \\
\hline 9 & 24.96 & 25.89 & 25.41 & 25.16 & 26.06 & 25.65 \\
\hline 10 & 25.61 & 26.15 & 25.84 & 25.78 & 26.11 & 25.95 \\
\hline 11 & 25.52 & 26.47 & 25.88 & 25.81 & 26.83 & 26.17 \\
\hline 12 & 25.57 & 26.38 & 25.98 & 25.61 & 26.54 & 26.10 \\
\hline 13 & 25.80 & 26.71 & 26.04 & 26.16 & 27.13 & 26.42 \\
\hline 14 & 25.65 & 26.36 & 25.95 & 26.15 & 26.67 & 26.40 \\
\hline
\end{tabular}

Because, as it was predictable, different values of the skin temperatures for each volunteer were measured, the average of their $t_{m s k}$ was used for the calculations.

Whereas the PMV permits to directly assess the level of the thermal comfort perceived by the occupants, the equivalent temperature needs to be interpreted in terms of perception of the thermal sensation and comfort. Actually, the various parts of the body perceive different thermal comfort sensations when they are exposed to the same equivalent temperature. For this reason European Standard EN ISO 14505-2 indicates both summer and winter comfort zones related to the whole body or the different $16 \mathrm{seg}$ ments in which the body may be subdivided. Table 4 lists the whole body comfort zones that refer to a winter and summer clothing of 1.0 and 0.6 clo, respectively. Because the thermal comfort zones are defined for people sitting into a vehicle, no correction for to the additional insulation due to the seats has to be considered.

Equivalent temperature $t_{e q}^{*}$ was calculated using the data of the measured mean skin temperature in Eq. (9) and evaluating $Q_{l}$ by means of Eqs. (15)-(17). To calculate clothing area factor $f_{c l}$ and convection heat transfer coefficient $h_{c}$, Eqs. (1) and (2) were used. Radiation heat transfer coefficient $h_{r}$ was evaluated by means of the following equation proposed by the ASHRAE (2009):

$h_{r}=4 \varepsilon \sigma \frac{A_{r}}{A_{D}}\left(273.15+\frac{t_{c l}+t_{m r}}{2}\right)^{3}$

where:

$\varepsilon=$ average emissivity of clothing surface, typically 0.95

$\sigma=$ Stefan-Boltzmann constant, $5.67 \cdot 10^{-8} \mathrm{~W} / \mathrm{m}^{2} \mathrm{~K}^{4}$

$A_{r}=$ effective radiation area of body $\left[\mathrm{m}^{2}\right]$

$A_{D}=$ area of body $\left[\mathrm{m}^{2}\right]$

Table 6

Thermal sensation scales and zones.

\begin{tabular}{|c|c|c|c|c|c|c|}
\hline \multicolumn{2}{|c|}{$\begin{array}{l}\text { Predicted mean } \\
\text { vote }\end{array}$} & \multicolumn{2}{|c|}{$\begin{array}{l}\text { Mean thermal } \\
\text { vote }\end{array}$} & \multicolumn{2}{|c|}{$\begin{array}{l}\text { Thermal } \\
\text { sensation zones }\end{array}$} & \multirow[t]{2}{*}{ Summer boundaries } \\
\hline+3 & Hot & +3 & $\begin{array}{l}\text { Much too } \\
\text { hot }\end{array}$ & & & \\
\hline+2 & Warm & +2 & Too hot & 5 & Too hot & $t_{e q}<20.0^{\circ} \mathrm{C}$ \\
\hline+1 & $\begin{array}{l}\text { Slightly } \\
\text { warm }\end{array}$ & +1 & $\begin{array}{l}\text { Warm but } \\
\text { comfortable }\end{array}$ & 4 & $\begin{array}{l}\text { Warm but } \\
\text { comfortable }\end{array}$ & $20.0^{\circ} \mathrm{C}<t_{e q}<23.8^{\circ} \mathrm{C}$ \\
\hline 0 & Neutral & 0 & Neutral & 3 & Neutral & $23.8^{\circ} \mathrm{C}<t_{e q}<26.7^{\circ} \mathrm{C}$ \\
\hline-1 & $\begin{array}{l}\text { Slightly } \\
\text { cool }\end{array}$ & -1 & $\begin{array}{l}\text { Cold but } \\
\text { comfortable }\end{array}$ & 2 & $\begin{array}{l}\text { Cold but } \\
\text { comfortable }\end{array}$ & $26.7^{\circ} \mathrm{C}<t_{e q}<30.0^{\circ} \mathrm{C}$ \\
\hline-2 & Cool & -2 & Too cold & 1 & Too cold & $t_{e q}>30.0^{\circ} \mathrm{C}$ \\
\hline-3 & Cold & -3 & $\begin{array}{l}\text { Much too } \\
\text { cold }\end{array}$ & & & \\
\hline
\end{tabular}

Flight 1 - Palermo-Verona - 8 Sep. 2011

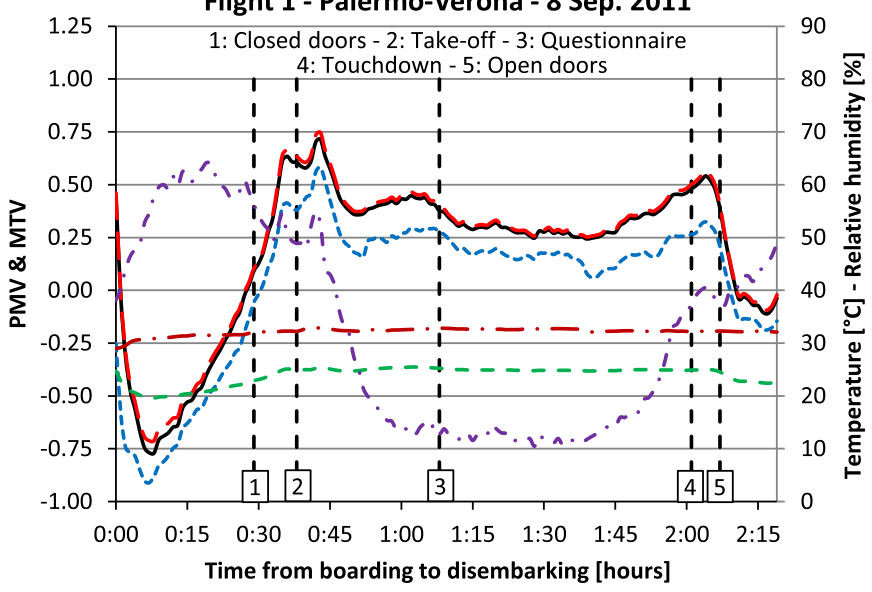

$$
\begin{array}{|lll|}
\hline \text { - PMV } & ----- \text { MTV meas. }-\cdots-\cdot \text { R.H. } \\
\text { - MTV calc. }---- \text { Tair } & -\cdots \text { Tskin } \\
\hline
\end{array}
$$

Fig. 4. PMV, MTV, temperature and humidity variations during flight 1 .

The ratio $A_{r} / A_{D}$ was assumed equal to 0.7 for a sitting person (Fanger, 1967). The calculations of $t_{e q}^{*}$ were also performed using Fanger Eqs. (13) -(17) and adopting Eq. (20) to evaluate the skin temperature. Table 5 summarizes the results of the calculations.

The values of the equivalent temperature are contained mostly in the summer zone 3 of Table 4. The average equivalent temperature calculated with the Fanger equations ranged from $25.41{ }^{\circ} \mathrm{C}$ to $26.27{ }^{\circ} \mathrm{C}$ whereas it varied between $25.25{ }^{\circ} \mathrm{C}$ and $26.42{ }^{\circ} \mathrm{C}$ when the measured data of the skin temperature were used. The differences between the values obtained using Eq. (19) and the ones based on the measured skin temperature were quite small and never surpassed $0.66{ }^{\circ} \mathrm{C}$. The minimum values of the equivalent temperature were never smaller than the lower threshold of the summer comfort zone 3; the upper threshold of the summer comfort zone 3 was seldom exceeded. Consequently, considering the summer conditions that are typically present in Italy until the beginning of October, it is predictable that the passengers would perceive a neutral thermal sensation. Because the PMV and the equivalent temperature predict thermal sensations that are qualitatively quite similar, it seemed interesting to

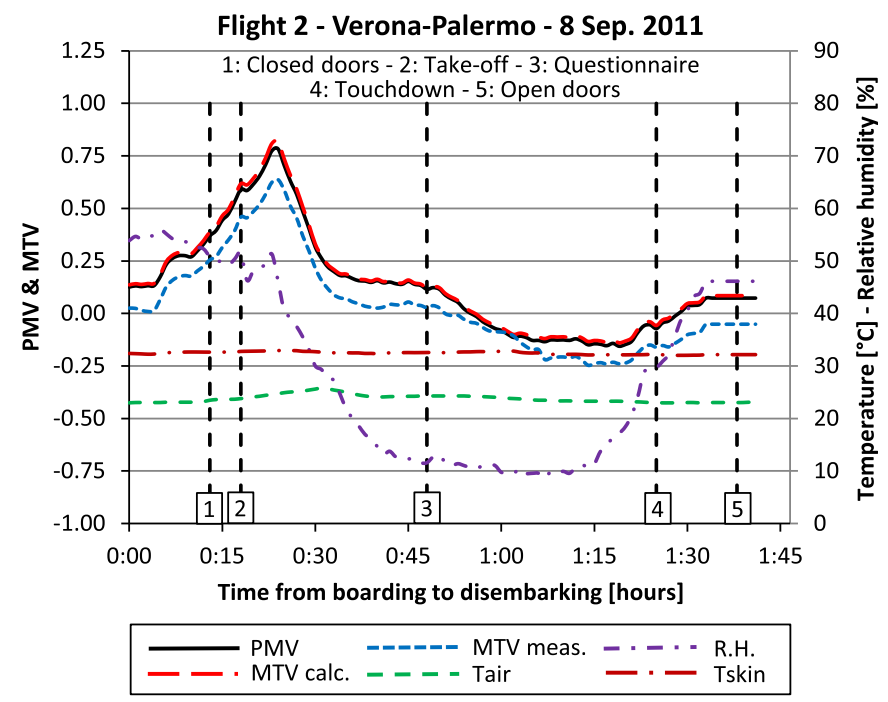

Fig. 5. PMV, MTV, temperature and humidity variations during flight 2 . 


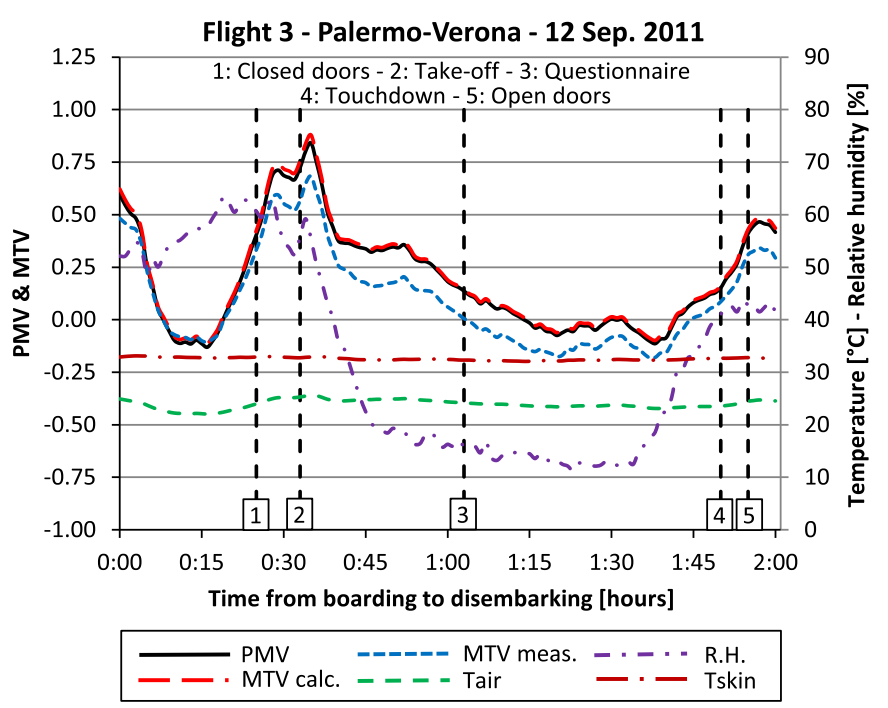

Fig. 6. PMV, MTV, temperature and humidity variations during flight 3.

better investigate on the correlation that may link such environmental indexes.

\section{A correlation between the PMV and the MTV}

In the experimental studies performed with thermal manikins, the thermal sensations were expressed using the MTV, which is based on a seven points scale. The heat fluxes from manikins were compared to the MTVs in order to define a relation with the equivalent temperature. Table 6 summarizes the thermal sensation scales of the PMV and MTV along with the thermal sensation zones of the equivalent temperature.

Comparing the thermal sensation scales listed in Table 6, it is evident that the PMV does not perfectly correspond to the MTV, and vice versa. At first sight the PMV thermal sensation scale seems to be more gradual than the MTV scale. Moreover, each value of the PMV indicates a precise and distinguishable sensation whereas the MTV scale seems to assess only whether thermal conditions are still acceptable or quite intolerable.

Because the temperature in the middle of the summer thermal sensation zone 3 corresponds to $25.25{ }^{\circ} \mathrm{C}$, the values of the

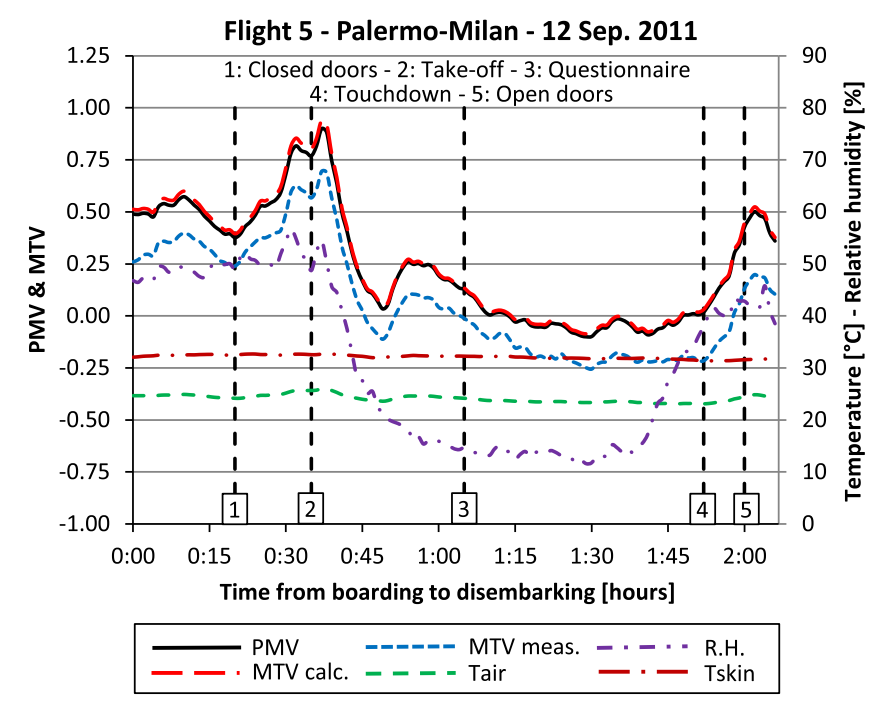

Fig. 8. PMV, MTV, temperature and humidity variations during flight 5.

equivalent temperature listed in Table 5 result averagely closer to the upper threshold of the summer thermal sensation zone 3 than to the lower limit. Such condition corresponds to a thermal sensation that should be a bit warmer than "neutral" and seems more similar to the "slightly warm" sensation of the PMV scale.

In order to go from qualitative to quantitative considerations, one may consider the existence of a direct numerical correlation between PMV and MTV via the equivalent temperature. To define such correlation it may be intuitively supposed that point 0 of the MTV scale corresponds to point 0 of the PMV scale and is located in the middle of the thermal sensation zone 3 , where the equivalent temperature is $25.25^{\circ} \mathrm{C}$ in summer conditions. Moreover, it may be empirically assumed that points +1 and -1 of the MTV scale match points +1 and -1 of the PMV scale, respectively. Point +1 of the MTV scale may be set in the middle of the summer thermal sensation zone 4 , where the equivalent temperature is $28.35^{\circ} \mathrm{C}$, and point -1 of the MTV scale may be matched to $21.9^{\circ} \mathrm{C}$, which is the equivalent temperature in the middle of the summer thermal sensation zone 2. Moreover, it may be assumed that the MTV linearly varies with the equivalent temperature into the range from -1 to +1 .

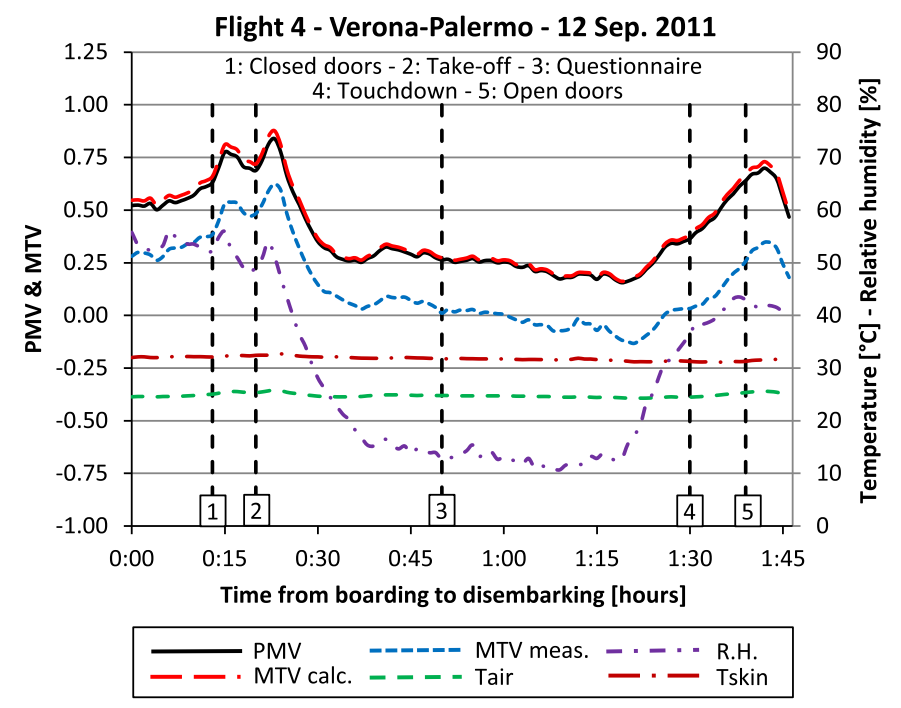

Fig. 7. PMV, MTV, temperature and humidity variations during flight 4 .

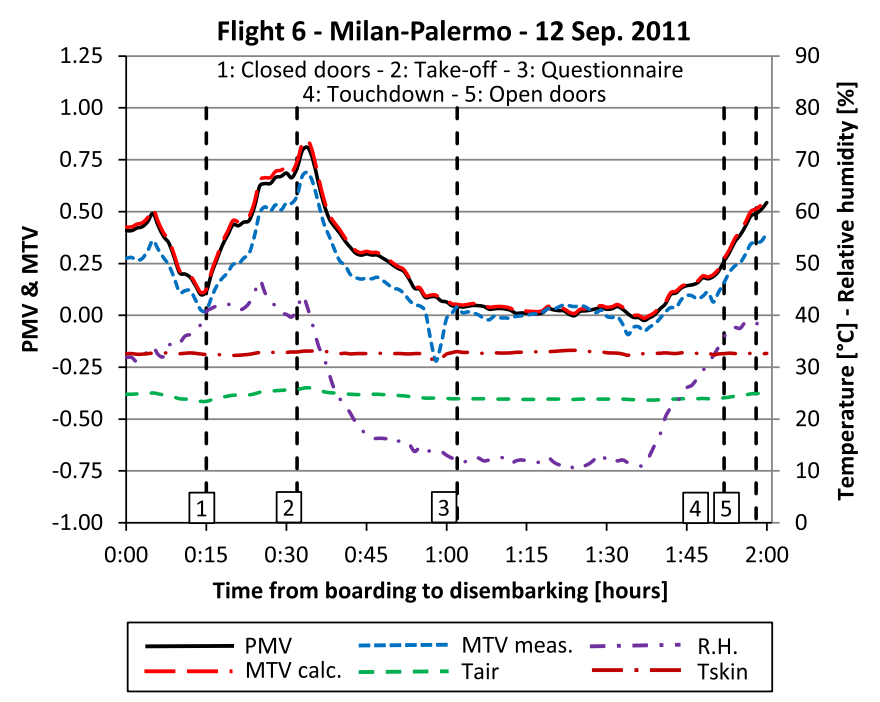

Fig. 9. PMV, MTV, temperature and humidity variations during flight 6. 


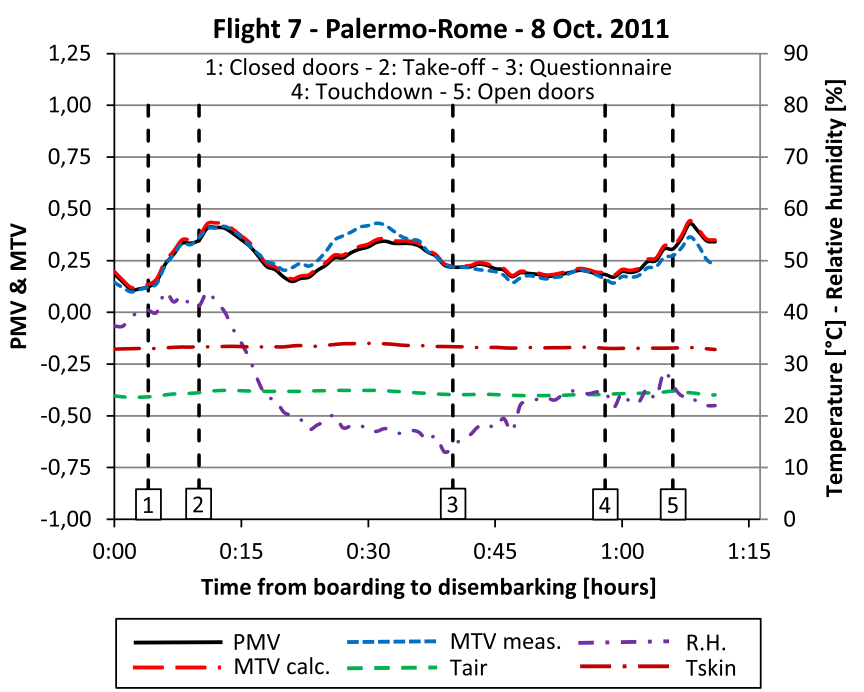

Fig. 10. PMV, MTV, temperature and humidity variations during flight 7 .

To verify the reliability of the adopted approach, the PMVs evaluated during all flights were compared to the MTVs obtained from the equivalent temperature on the basis of the correspondence previously described. Unfortunately, such approach did not yield consistent results. Actually, comparing the values of the PMV with the values of the MTV, it was observed that, in correspondence of PMV $=0$, the MTV was generally equal to about -0.15 . Moreover, the MTV varied between values that were always smaller than the values of the PMV.

In order to compensate such difference and make the MTV correspond to the PMV into the range bounded by -1 and +1 , the following relationships were used:

$\mathrm{MTV}=\frac{t_{e q}^{*}-t_{0}}{t_{+1}-t_{0}}+0.15$ if $t_{e q}^{*}>t_{0}$

$\mathrm{MTV}=\frac{t_{e q}^{*}-t_{0}}{t_{0}-t_{-1}}+0.15$ if $t_{e q}^{*}<t_{0}$

where:

$t_{-1}=t_{23}-0.4\left(t_{23}-t_{12}\right)$

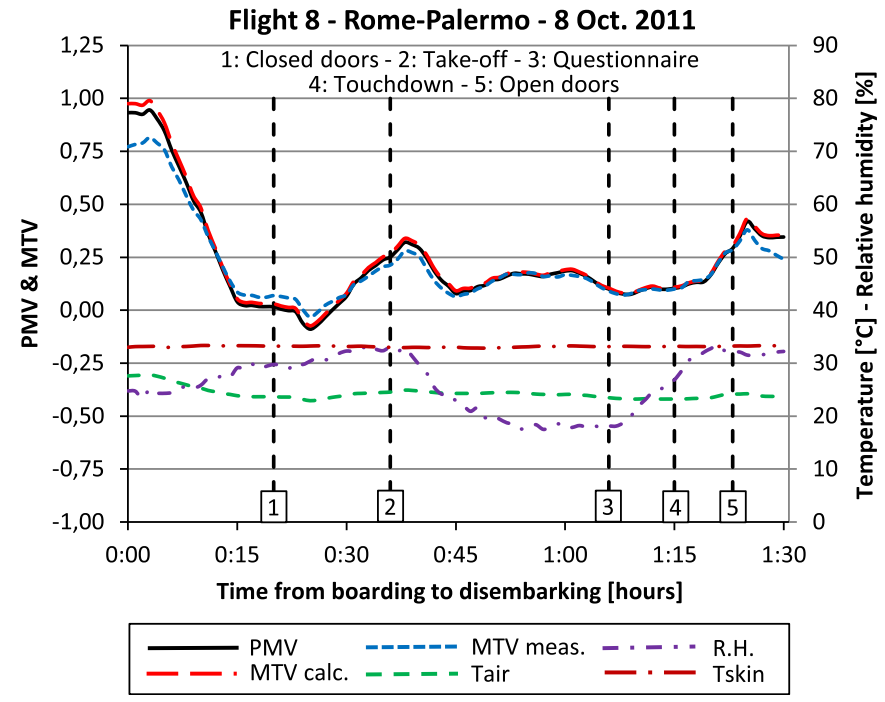

Fig. 11. PMV, MTV, temperature and humidity variations during flight 8 .

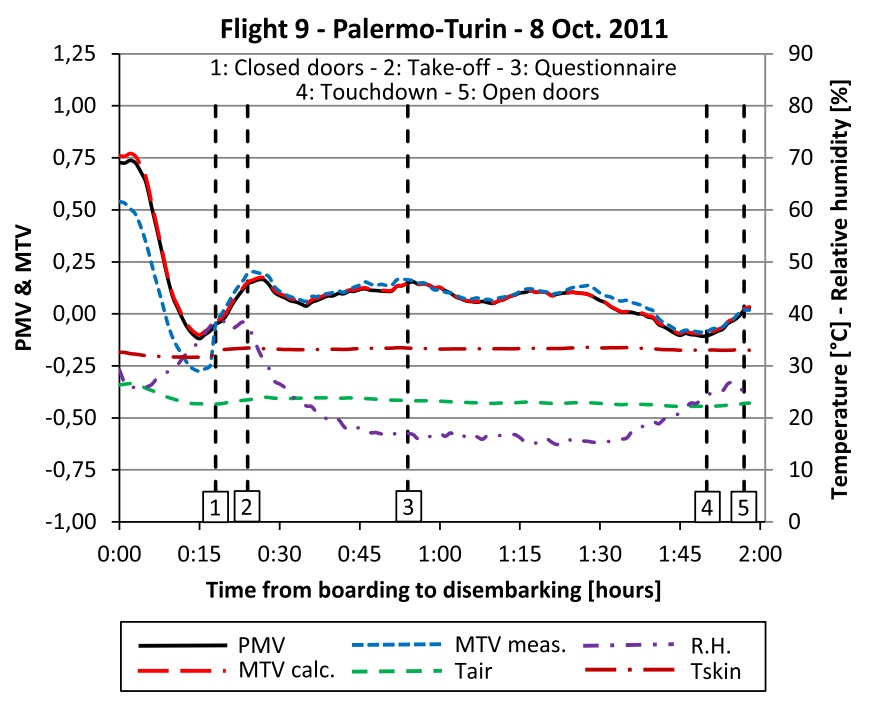

Fig. 12. PMV, MTV, temperature and humidity variations during flight 9 .

$t_{0}=0.5\left(t_{23}+t_{24}\right)$

$t_{+1}=t_{34}+0.4\left(t_{45}-t_{34}\right)$

and $t_{12}=20^{\circ} \mathrm{C}, t_{23}=23.8^{\circ} \mathrm{C}, t_{34}=26.7^{\circ} \mathrm{C}$ and $t_{45}=30^{\circ} \mathrm{C}$, which are the temperature bounding thermal sensation zones 2,3 and 4 . In Figs. 4-17 the PMVs are compared with the MTVs obtained from the calculus of the equivalent temperature performed by means of the Fanger equations (MTV calc.) or using the values of the skin temperature measured on volunteers (MTV meas.); the figures also depict the air temperature, relative humidity and mean skin temperature measured during flights.

Significant similarities between the values of the PMV and the MTV can be observed in Figs. 4-17. The MTVs calculated using the Fanger equations overlap the PMVs for almost all flights. A satisfactory agreement between the values of the MTV calculated with the Fanger equations and the values of the MTV calculated by means of the mean skin temperature measured on volunteers can be observed for flights 7, 8, 9, 10 and 12 . In flights 1-6 the values of the MTV evaluated using the measured skin temperature are

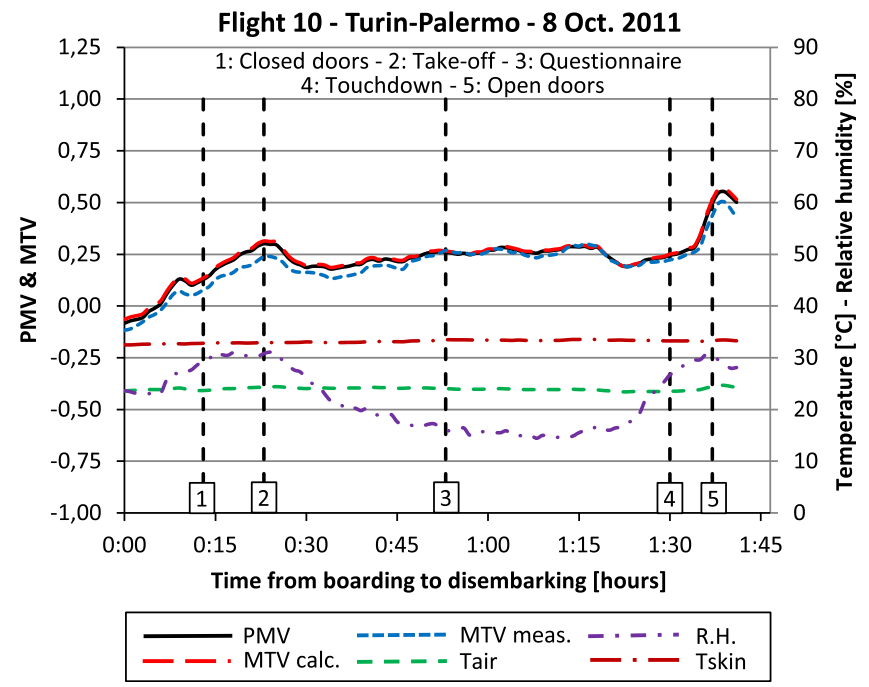

Fig. 13. PMV, MTV, temperature and humidity variations during flight 10. 


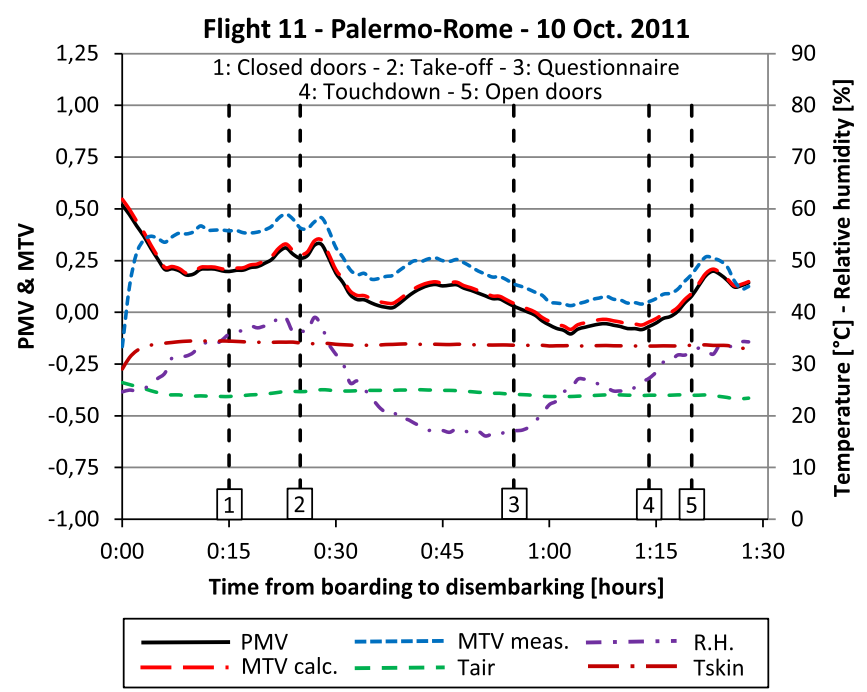

Fig. 14. PMV, MTV, temperature and humidity variations during flight 11.

smaller than the MTV evaluated with the Fanger equations; the opposite is observed for flights 11,13 and 14 . Such a behaviour, which accounts for the statistical nature of the measurements performed on human subjects, seems to confirm the reliability of the proposed approach. Table 7 lists the minimum and maximum differences between the PMVs, the MTVs calculated with the Fanger equations and the MTVs evaluated using the measured values of the skin temperature; also the average values of the absolute differences are indicated.

The minimum value of the absolute difference between the PMV and the MTV, calculated with the Fanger equations, was observed for flight 9 and resulted equal to 0.0073 ; in flight 1 it was reached the maximum value of 0.0589 . The minimum difference between the PMV and the MTV, calculated with the Fanger equations, varied between -0.0009 and 0.0087 and the maximum difference ranged from 0.0187 to 0.0589 . The MTVs based on the measured values of the skin temperature resulted less accurate. A minimum value of the absolute difference of 0.0301 was obtained for flight 10 , whereas for flight 4 the maximum value reached 0.2579 . On the basis of the observed differences it is possible to affirm that the proposed relationship is able to link the equivalent temperature

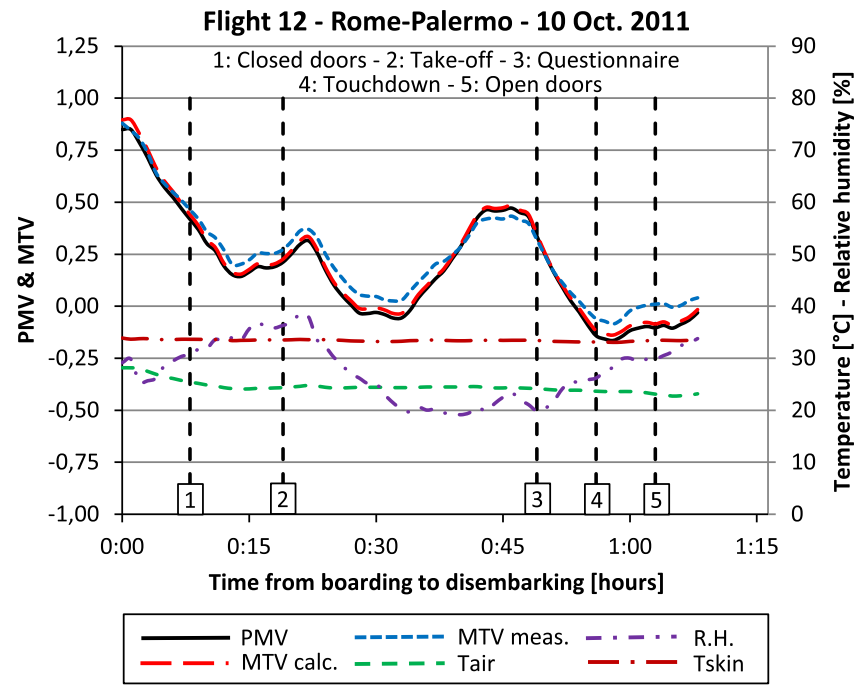

Fig. 15. PMV, MTV, temperature and humidity variations during flight 12 .

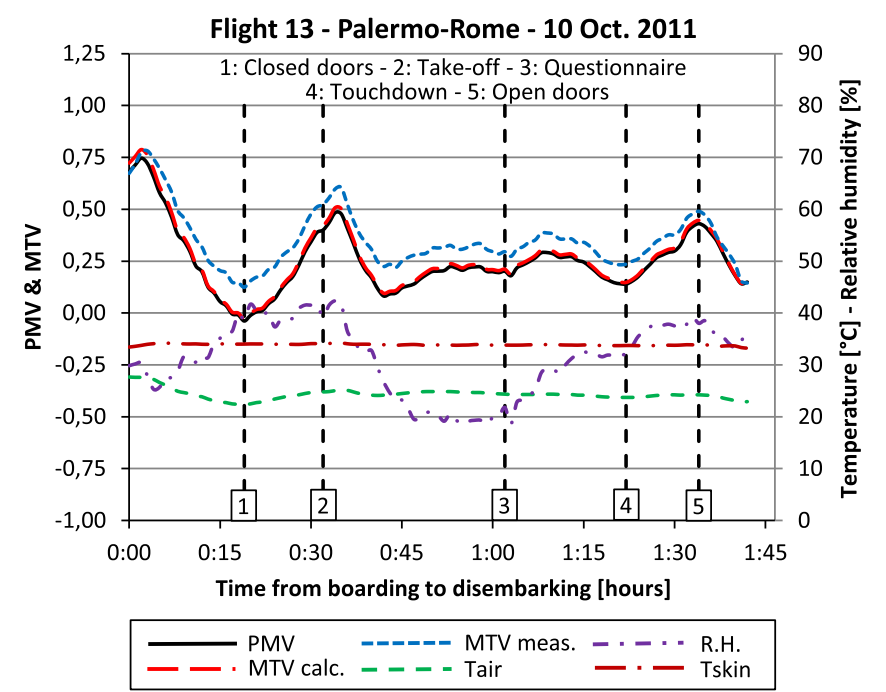

Fig. 16. PMV, MTV, temperature and humidity variations during flight 13 .

and the MTV to the PMV with an adequate level of accuracy within the range of the analysed values.

\section{Conclusions}

An experimental study upon the thermal comfort conditions inside the cabin of an Airbus A319 aircraft during 14 short-haul domestic flights is presented. The study confirmed that the values of the air temperature inside cabins are quite acceptable whereas the relative humidity can be very small, especially at cruising altitudes where airliners fly for the most part of the time; the calculated values of the PMV agreed with the answers of the passengers who were asked to fill in questionnaires:

- the average of the air temperature varied between $23.1^{\circ} \mathrm{C}$ and $25.0^{\circ} \mathrm{C}$, with a minimum value of $22.2^{\circ} \mathrm{C}$ and a maximum value of $26.0^{\circ} \mathrm{C}$;

- the average of the mean radiant temperature varied between $24.0^{\circ} \mathrm{C}$ and $26.2^{\circ} \mathrm{C}$;

- the relative humidity ranged from a minimum of $8.7 \%$ to a maximum of $59.2 \%$ and its average value varied between $17.9 \%$ and $27.0 \%$;

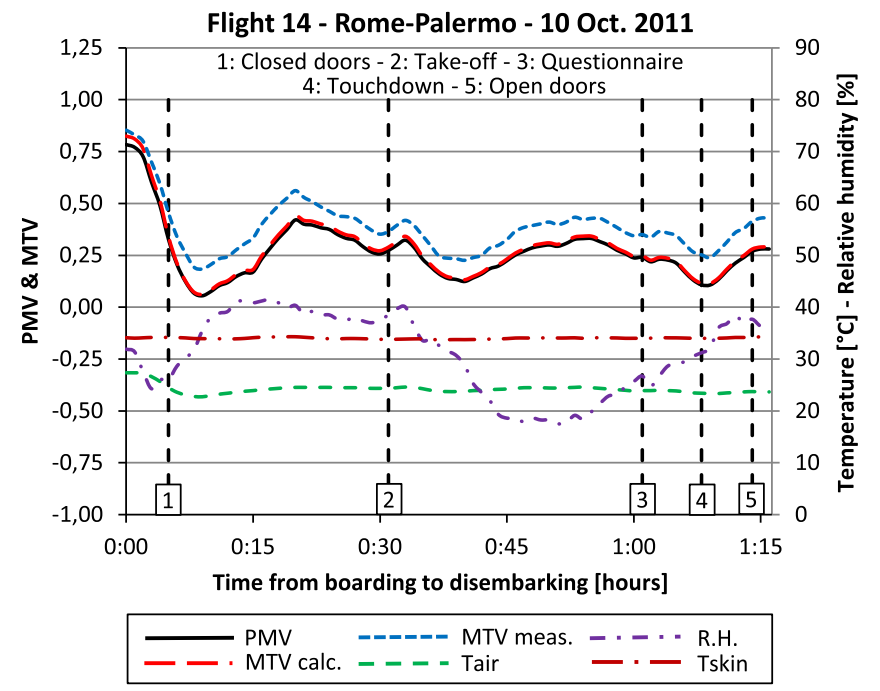

Fig. 17. PMV, MTV, temperature and humidity variations during flight 14 . 
Table 7

Differences between PMV and MTV during flights. In each column underline and bold are the minimum and maximum difference value respectively.

\begin{tabular}{|c|c|c|c|c|c|c|c|c|c|}
\hline \multirow[t]{2}{*}{ Flight no. } & \multicolumn{3}{|c|}{ MTV $_{\text {calc. }}$ PMV } & \multicolumn{3}{|c|}{$\mathrm{MTV}_{\text {meas. }}-\mathrm{PMV}$} & \multicolumn{3}{|c|}{$\mathrm{MTV}_{\text {meas. }}-\mathrm{MTV}_{\text {calc. }}$} \\
\hline & Min. & Max. & Absolute average & Min. & Max. & Absolute average & Min. & Max. & Absolute average \\
\hline 1 & 0.0087 & 0.0589 & 0.0195 & -0.6934 & -0.0630 & 0.1555 & -0.7134 & -0.0790 & 0.1750 \\
\hline 2 & $\overline{0.0060}$ & $\overline{0.0349}$ & $\overline{0.0143}$ & -0.1499 & 0.0067 & 0.0984 & -0.1848 & -0.0076 & 0.1124 \\
\hline 3 & 0.0066 & 0.0382 & 0.0156 & -0.1717 & 0.0312 & 0.0966 & -0.1969 & 0.0125 & 0.1100 \\
\hline 4 & 0.0063 & 0.0377 & 0.0178 & -0.3897 & -0.1793 & 0.2579 & -0.4173 & -0.1983 & 0.2756 \\
\hline 5 & 0.0064 & 0.0406 & 0.0168 & -0.3026 & -0.0961 & $\overline{0.1709}$ & -0.3254 & -0.1066 & $\overline{0.1877}$ \\
\hline 6 & 0.0064 & 0.0355 & 0.0142 & -0.3095 & 0.0436 & 0.0894 & -0.3174 & 0.0331 & 0.1025 \\
\hline 7 & 0.0052 & 0.0218 & 0.0115 & -0.1143 & 0.1064 & 0.0311 & -0.1231 & 0.0934 & 0.0339 \\
\hline 8 & 0.0040 & 0.0442 & 0.0135 & -0.1609 & 0.0644 & 0.0341 & -0.2036 & 0.0487 & 0.0407 \\
\hline 9 & -0.0009 & 0.0333 & 0.0073 & -0.2887 & 0.0570 & 0.0498 & -0.3141 & 0.0542 & 0.0493 \\
\hline 10 & 0.0008 & 0.0187 & 0.0082 & -0.0764 & 0.0159 & 0.0301 & -0.0906 & 0.0116 & 0.0373 \\
\hline 11 & 0.0060 & 0.0286 & 0.0158 & -0.6837 & $\underline{0.2100}$ & 0.1356 & -0.7123 & $\underline{0.2002}$ & 0.1223 \\
\hline 12 & 0.0062 & 0.0465 & 0.0185 & -0.0439 & 0.1128 & 0.0580 & -0.0560 & 0.0948 & 0.0474 \\
\hline 13 & 0.0019 & 0.0414 & 0.0140 & -0.0080 & 0.1670 & 0.1027 & -0.0491 & 0.1558 & 0.0906 \\
\hline 14 & 0.0037 & 0.0409 & 0.0125 & 0.0601 & 0.1676 & 0.1162 & 0.0197 & 0.1533 & 0.1037 \\
\hline
\end{tabular}

- the calculated values of the PMV ranged from -0.16 to 0.90 from take-off to touchdown; the PPD varied between $5.0 \%$ and $22.1 \%$.

The experimental data were used to define a correlation linking the equivalent temperature and the MTV to the PMV. The results of the study proved the validity and reliability of the proposed correlation:

- the minimum value of the absolute difference between the PMV and the MTV calculated with the Fanger equations resulted equal to 0.0073 ; the maximum difference reached a value of 0.0589;

- the MTVs based on the measured values of the skin temperature resulted less accurate because a minimum value of the absolute difference of 0.0301 , and a maximum value of 0.2579 , was observed.

Thanks to the proposed correlation, the equivalent temperature and the MTV, which were specifically proposed to evaluate the thermal sensation in vehicles, can be an effective alternative to the PMV for the assessment of the thermal comfort in airplanes or other occupied places.

\section{Acknowledgments}

The Authors wish to thank the WindJet Airline Company and the Commander D. Catalisano for their valuable support, as well as the PHD students M. Ariolo and D. Giurintano who carried out the measurement campaign onboard the WindJet Aircrafts.

\section{Nomenclature}

\begin{tabular}{|c|c|}
\hline$A_{D}$ & area of body $\left[\mathrm{m}^{2}\right]$ \\
\hline$A_{r}$ & effective radiation area of body $\left[\mathrm{m}^{2}\right]$ \\
\hline C & convective heat loss per unit area $\left[\mathrm{W} / \mathrm{m}^{2}\right]$ \\
\hline$C_{\text {res }}$ & rate of sensible heat loss due to respiration $\left[\mathrm{W} / \mathrm{m}^{2}\right]$ \\
\hline$E_{\text {dif }}$ & $\begin{array}{l}\text { rate of latent heat loss due to water diffusion through the } \\
\text { skin }\left[\mathrm{W} / \mathrm{m}^{2}\right]\end{array}$ \\
\hline$E_{\text {res }}$ & rate of latent heat loss due to respiration $\left[\mathrm{W} / \mathrm{m}^{2}\right]$ \\
\hline$E_{r S w}$ & rate of latent heat loss due to sweating $\left[\mathrm{W} / \mathrm{m}^{2}\right]$ \\
\hline$f_{c l}$ & clothing area factor \\
\hline$h_{c}$ & convection heat transfer coefficient $\left[\mathrm{W} / \mathrm{m}^{2}{ }^{\circ} \mathrm{C}\right]$ \\
\hline$h_{r}$ & radiation heat transfer coefficient $\left[\mathrm{W} / \mathrm{m}^{2}{ }^{\circ} \mathrm{C}\right]$ \\
\hline$h_{r c}$ & combined heat transfer coefficient $\left[\mathrm{W} / \mathrm{m}^{2}{ }^{\circ} \mathrm{C}\right]$ \\
\hline$I_{c l}$ & clothing insulation [clo] \\
\hline$M$ & rate of metabolic heat production $\left[\mathrm{W} / \mathrm{m}^{2}\right]$ \\
\hline & our pressure in the cabin [kPa] \\
\hline
\end{tabular}

$t_{a} \quad$ air temperature $\left[{ }^{\circ} \mathrm{C}\right]$

$t_{c l} \quad$ mean temperature of the outer surface of the clothed body $\left[{ }^{\circ} \mathrm{C}\right]$

$t_{\text {eq }} \quad$ equivalent temperature $\left[{ }^{\circ} \mathrm{C}\right]$

$t_{e q}^{*} \quad$ equivalent temperature of the human body [ $\left.{ }^{\circ} \mathrm{C}\right]$

$t_{m r}$ mean radiant temperature of the environment $\left[{ }^{\circ} \mathrm{C}\right]$

$t_{m s k} \quad$ mean skin temperature $\left[{ }^{\circ} \mathrm{C}\right]$

$t_{s} \quad$ surface temperature $\left[{ }^{\circ} \mathrm{C}\right]$

$t_{s k} \quad$ skin temperature $\left[{ }^{\circ} \mathrm{C}\right]$

$t_{0}$ temperature where $\mathrm{MTV}=0\left[{ }^{\circ} \mathrm{C}\right]$

$t_{1} \quad$ left chest skin temperature $\left[{ }^{\circ} \mathrm{C}\right]$

$t_{2} \quad$ right calf skin temperature $\left[{ }^{\circ} \mathrm{C}\right]$

$t_{3} \quad$ left forearm skin temperature $\left[{ }^{\circ} \mathrm{C}\right]$

$t_{-1} \quad$ temperature where MTV $=-1\left[{ }^{\circ} \mathrm{C}\right]$

$t_{+1}$ temperature where MTV $=+1\left[{ }^{\circ} \mathrm{C}\right]$

$t_{12}$ temperature bounding thermal sensation zone $2\left[{ }^{\circ} \mathrm{C}\right]$

$t_{23}$ temperature bounding thermal sensation zones 2 and 3 $\left[{ }^{\circ} \mathrm{C}\right]$

$t_{34}$ temperature bounding thermal sensation zones 3 and 4 $\left[{ }^{\circ} \mathrm{C}\right]$

$t_{45}$ temperature bounding thermal sensation zone $4\left[{ }^{\circ} \mathrm{C}\right]$

$Q_{s} \quad$ sensible heat loss per unit area $\left[\mathrm{W} / \mathrm{m}^{2}\right]$

$Q_{l} \quad$ latent heat loss $\left[\mathrm{W} / \mathrm{m}^{2}\right]$

$Q_{T} \quad$ total heat loss $\left[\mathrm{W} / \mathrm{m}^{2}\right]$

$R \quad$ radiation heat loss per unit area $\left[\mathrm{W} / \mathrm{m}^{2}\right]$

$R_{c l} \quad$ clothing thermal resistance $\left[\mathrm{m}^{2} \mathrm{~K} / \mathrm{W}\right]$

$V \quad$ air velocity $[\mathrm{m} / \mathrm{s}]$

$W \quad$ rate of mechanical work accomplished $\left[\mathrm{W} / \mathrm{m}^{2}\right]$

$\varepsilon \quad$ average emissivity of clothing surface

$\sigma \quad$ Stefan-Boltzmann constant $\left[\mathrm{W} / \mathrm{m}^{2} \mathrm{~K}^{4}\right]$

\section{References}

ANSI/ASHRAE Standard 55-2004, 2004. Thermal Environmental Conditions for Human Occupancy.

ASHRAE Handbook - Fundamentals, 2009.

Backman, H., Haghighat, F., 2000. Air quality and ocular discomfort aboard commercial aircraft. Optometry 71, 653-656.

Bergau, L., 1999. Radiation exposure and air quality aboard commercial airplanes. Z. für ärztliche Fortbild. Oual. 93, 491-494.

Blettner, M., Zeeb, H., Langner, I., Hammer, G.P., Schafft, T., 2002. Mortality from cancer and ther causes among airline cabin attendants in Germany, 1960-1997. Am. J. Epidemiol. 156, 556-565.

Brundrett, G., 2001. Comfort and health in commercial aircraft: a literature review. J. R. Soc. Health 121 (1), 29-37.

Bulcao, C.F., Frank, S.M., Raja, S.N., Tran, K.M., Goldstein, D.S., 2000. Relative contribution of core and skin temperatures to thermal comfort in humans. J. Therm. Biol. 25, 147-150.

Burton, A., 1935. Human calorimetry: II. The average temperature of the tissues of the body three figures. J. Nutr. 9, 261-280. 
Butler, G.C., Nicholas, J., Lackland, D.T., Friedberg, W., 2000. Perspectives of those impacted: airline pilot's perspective. Health Phys. 79, 602-607.

Cavallo, D., Tomao, P., Marinaccio, A., Perniconi, B., Setini, A., Palmi, S., Iavicoli, S., 2002. Evaluation of DNA damage in flight personnel by comet assay. Mutat. Res. $516,148-152$.

Chen, Q., Jones, B.W., Loo, S.M., Nazaroff, W.W., Overfelt, R.A., Spengler, J.D. Weisel, C.P., Weschler, C.J., 2010. Report to the FAA on the Airliner Cabin Environment. Report No. RITE-ACER-CoE-2010-1. National Air Transportation Center of Excellence for Research in the Intermodal Transport Environment (RITE) - Airliner Cabin Environmental Research (ACER) Program.

European Standard EN ISO 14505-2, 2007. Ergonomics of the Thermal Environment - Evaluation of Thermal Environments in Vehicles - Part 2: Determination of Equivalent Temperature.

Fanger, P.O., 1967. Calculation of thermal comfort: introduction of a basic comfort equation. ASHRAE Trans. 73 (2). III.4.1.

Fanger, P.O., 1970. Thermal Comfort Analysis and Applications in Environmental Engineering. McGraw-Hill, New York.

Fanger, P.O., 1982. Thermal Comfort. Robert E. Krieger, Malabar, FL.

Gagge, A.P., Stolwijk, A.J., Salting, B., 1969. Comfort and thermal sensations and associated physiological responses during exercise at various ambient temperatures. Environ. Res. 2, 209-229.

Gameiro da Silva, M.C., 2002. Measurements of comfort in vehicles. Meas. Sci. Technol. 13, R41-R60.

Giaconia, C., Orioli, A., Di Gangi, A., 2013. Air quality and relative humidity in commercial aircrafts: an experimental investigation on short-haul domestic flights. Build. Environ. 67, 69-81.

Grün, G., Trimmel, M., Holm, A., 2012. Low humidity in the aircraft cabin environment and its impact on well-being - results from laboratory study. Build. Environ. 47, 23-31.

Haghighat, F., Allard, F. Megri, A.C., Blondeau, P. Shimotakahara, R., 1999. Measurement of thermal comfort and indoor air quality aboard 43 flights on commercial airlines. Indoor Built Environ. 8, 58-66.

Hammar, N., Linnersjo, A., Alfredsson, L., Dammstrom, B.G., Johansson, M. Eliasch, H., 2002. Cancer incidence in airline and military pilots in Sweden 1961-1996. Aviat. Space Environ. Med. 73, 2-7.

Hasebe, Y., Iriki, M., Takahasi, K., 1995. Usefulness of R-R interval and its variability in evaluation of thermal comfort. Int. J. Biometeorol. 38, 116-121.

Hocking, M.B., 2000. Passenger aircraft cabin air quality: trends, effects, societal costs, proposals. Chemiosphere 41, 603-615.

Hocking, M.B., 2002. Trends in cabin air quality of commercial aircraft: industry and passenger perspectives. Rev. Environ. Health 17, 1-49.

Huizenga, C., Zhang, H., Arens, E., Wang, D., 2004. Skin and core temperature response to partial- and whole-body heating and cooling. J. Therm. Biol. 29, $549-558$.

Lee, S., Poon, C., Li, X., Luk, F., 1999. Indoor air quality investigation on commercial aircraft. Indoor Air 9, 180-187.

Lee, S.C., Poon, C.S., Li, X.D., Luk, F., Chang, M., 2000. Questionnaire Survey to Evaluate the Health and Comfort of Cabin Crew. In: Nagda (Ed.), Air Quality and Comfort in Airliner Cabins. American Society for Testing and Materials, West Conshohocken, PA, pp. 259-268.

Lim, M.K., 2002. Cosmic rays: are air crew at risk? Occup. Environ. Med. 59, 428-432.

Lindgren, T., Andersson, K., Dammstrom, B.G., Norback, D., 2002. Ocular, nasal, dermal and general symptoms among commercial airline crews. Int. Arch. Occup. Environ. Health 75 (7), 475-483.

Lindgren, T., Norbäck, D., 2005. Health and perception of cabin air quality among Swedish commercial airline crew. Indoor Air 15 (s10), 65-72.

Lindgren, T., Norbäck, D., Wieslander, G., 2007. Perception of cabin air quality in airline crew related to air humidification, on intercontinental flights. Indoor Air 17 (3), 204-210

Liu, W., Lian, Z., Deng, Q., Liu, Y., 2011. Evaluation of calculation methods of mean skin temperature for use in thermal comfort study. Build. Environ. 46, 478-488.

McNeely, E., Spengler, J., Watson, J., 2011. Health Effects of Aircraft Cabin Pressure in Older and Vulnerable Passengers. Report No. RITE-ACER-CoE-2011-1. National Air Transportation Center of Excellence for Research in the Intermodal Transport Environment (RITE) - Airliner Cabin Environmental Research (ACER) Program.

Michaelis, S., 2003. A survey of health symptoms in BALPA Boeing 757 pilots. J. Occup. Health Saf. Aust. N. Z. 19, 253-261.
Muhm, M.D., Rock, P.B., McMullin, D.L., Jones, S.P., Lu, I.L., Eilers, K.D., Space, D.R., McMullen, A., 2007. Effect of aircraft cabin altitude on passenger discomfort. N. Engl. J. Med. 357, 18-27.

Nagda, N.L., Hodgson, M., 2001. Low relative humidity and aircraft cabin air quality. Indoor Air 11 (3), 200-214.

Nagda, N.L., Koontz, M.D., 2003. Review of studies on flight attendant health and comfort in airliner cabins. Aviat. Space Environ. Med. 74 (2), 101-109.

Nilsson, H.O., 2007. Thermal comfort evaluation with virtual manikin methods. Build. Environ. 42, 4000-4005.

Nilsson, H.O., Holmér, I., 2003. Comfort climate evaluation with thermal manikin methods and computer simulation models. Indoor Air 13, 28-37.

Nilsson, H.O., Holmér, I., Bohm, M., Norén, O., 1997. Equivalent temperature and thermal sensation. Comparison with subjective responses. In: Proceedings of Comfort in the Automotive Industry. Recent Development and Achievements. ATA, Bologna, pp. 157-162.

Olesen, B.W., 1984. How Many Sites are Necessary to Estimate a Mean Skin Temperature? Thermal Physiology Raven Press, New York, pp. 34-38.

Park, S., Hellwig, R.T., Grün, G., Holm, A., 2011. Local and overall thermal comfort in an aircraft cabin and their interrelations. Build. Environ. 46, 1056-1064.

Quintela, D. Adélio, G., Borges, C., 2004. Analysis of sensible heat exchanges from a thermal manikin. Eur. J. Appl. Physiol. 92, 663-668.

Rankin, W.L., Space, D.R., Nagda, N.L., 2000. Passenger comfort and the effect of air quality. In: ASTM STP, Nagda, N.L. (Eds.), Air Quality and Comfort in Airliner Cabins. American Society for Testing and Materials, West Conshohocken, PA, pp. 269-290.

Richards, M., Mattle, N., 2002. A sweating thermal manikin (SAM) developed to test complete clothing systems under normal and extreme conditions. In: RTO HFM Symposium, Blowing Hot and Cold: Protecting Against Climatic Extremes, vol. 4 , pp. $1-7$.

Rohles Jr., F.H., Nevins, R.G., 1971. The nature of thermal comfort for sedentary man. ASHRAE Trans. 77 (1), 239-246.

Ross, D., Crump, D., Hunter, C., Perera, E., Sheridan, A., 2003. Client Report: Extending Cabin Air Measurements to Include Older Aircraft Types Utilised in High Volume Short Haul Operation. BRE Environment.

Spengler, J.D., Vallarino, J., McNeely, E., Estephan, H., Sumner, A.L., 2012. In-Flight/ Onboard Monitoring: ACER's Component for ASHRAE 1262, Part 2. Report No. RITE-ACER-CoE-2012-6. 2012: National Air Transportation Center of Excellence for Research in the Intermodal Transport Environment (RITE) - Airliner Cabin Environmental Research (ACER) Program.

Spicer, C.W., Murphy, M.J., Holdren, M.W., Myers, J.D., MacGregor, I.C., Holloman, C., James, R.R., Tucker, K., Zaborski, R., 2004. Relate Air Quality and Other Factors to Comfort and Health Symptoms Reported by Passengers and Crew on Commercial Transport Aircraft; ASHRAE Project 1262.

Strøm-Tejsen, P., Wyon, D.P., Lagercrantz, L., Fang, L., 2005a. Occupant evaluation of 7-hour exposures in a simulated aircraft cabin - part 1: optimum balance between fresh air and supply and humidity. Indoor Air 40-45.

Strøm-Tejsen, P., Wyon, D.P., Zukowska, D., Jama, A., Fang, L., 2005b. Occupant evaluation of 7-hour exposures in a simulated aircraft cabin - part 2: thermal effects. Indoor Air 46-51.

Tripadvisor. 2012, http://www.multivu.com/mnr/49263-tripadvisor-surveyreveals-air-travel-on-the-rise-in-2012.

Wang, A., Zhang, Y., Sun, Y., Wang, X., 2008. Experimental study of ventilation effectiveness and air velocity distribution in an aircraft cabin mockup. Build. Environ. 43, 337-343.

Wang, F. 2008 September. A comparative introduction on sweating thermal manikins "Newton" and "Walter". In: 7th International Thermal Manikin and Modelling Meeting. University of Coimbra, pp. 1-7.

Wang, F., Kuklane, K., Gao, C., Holmér, I., 2010. Development of empirical equations to predict sweating skin surface temperature for thermal manikins in warm environments. In: The 3rd International Symposium on Textile Bioengineering and Informatics (TBIS), Shanghai, China, pp. 1-6.

Wyon, D., 1989. Use of thermal manikins in environmental ergonomics. Scand. J. Work Environ. Health 15 (Suppl. 1), 84-94.

Wyon, D., Larsson, S., Forsgren, B., Lundgren, I., 1989. Standard Procedures for Assessing Vehicle Climate with a Thermal Manikin. Technical paper series, no. 890049. Society of Automotive Engineers, Detroit. 